\title{
Patterns of aeolian deposition in subtropical Australia through the last glacial and deglacial periods
}

\author{
Richard J. Lewis ${ }^{\mathrm{a} *}$ (D), John Tibby ${ }^{\mathrm{b}}$, Lee J. Arnold ${ }^{\mathrm{a}}$, Patricia Gadd ${ }^{\mathrm{c}}$, Geraldine Jacobsen ${ }^{\mathrm{c}}$, Cameron Barr ${ }^{\mathrm{b}}$, Peter M. Negus ${ }^{\mathrm{d}}$, \\ Michela Mariani ${ }^{e}$, Daniel Penny ${ }^{\mathrm{f}}$, David Chittleborough" ${ }^{\mathrm{g}}$,, Edward Moss ${ }^{\mathrm{f}}$ \\ ${ }^{a}$ School of Physical Science, Environment Institute, Sprigg Geobiology Centre and Institute for Photonics and Advanced Sensing (IPAS), University of \\ Adelaide, North Terrace Campus, Adelaide, 5005, SA, Australia \\ ${ }^{\mathrm{b}}$ Geography, Environment and Population and Sprigg Geobiology Centre, University of Adelaide, North Terrace Campus, Adelaide, 5005, SA, Australia \\ ${ }^{c}$ Australian Nuclear Science and Technology Organisation (ANSTO), Locked Bag 2001, Kirrawee DC, NSW, 2232, Australia \\ ${ }^{\mathrm{d}}$ Queensland Department of Environment and Science, GPO Box 2454, Brisbane, Queensland, 4001, Australia \\ 'e School of Geography, University of Nottingham, University Park, Nottingham, NG7 2RD \\ ${ }^{\mathrm{f}}$ School of Geosciences, The University of Sydney, NSW 2006, Australia \\ ${ }^{\mathrm{g}}$ School of Physical Sciences, The University of Adelaide, Adelaide, South Australia 5005, Australia \\ ${ }^{\mathrm{h}}$ School of Science and Engineering, The University of the Sunshine Coast, Queensland 4556 \\ *Corresponding author email address: richard.lewis@ adelaide.edu.au
}

(Received June 12, 2020; AcCEPTED November 10, 2020)

\begin{abstract}
Debate about the nature of climate and the magnitude of ecological change across Australia during the last glacial maximum (LGM; 26.5-19 ka) persists despite considerable research into the late Pleistocene. This is partly due to a lack of detailed paleoenvironmental records and reliable chronological frameworks. Geochemical and geochronological analyses of a $60 \mathrm{ka}$ sedimentary record from Brown Lake, subtropical Queensland, are presented and considered in the context of climatecontrolled environmental change. Optically stimulated luminescence dating of dune crests adjacent to prominent wetlands across North Stradbroke Island (Minjerribah) returned a mean age of $119.9 \pm 10.6 \mathrm{ka}$; indicating relative dune stability soon after formation in Marine Isotope Stage 5. Synthesis of wetland sediment geochemistry across the island was used to identify dust accumulation and applied as an aridification proxy over the last glacial-interglacial cycle. A positive trend of dust deposition from ca. $50 \mathrm{ka}$ was found with highest influx occurring leading into the LGM. Complexities of comparing sedimentary records and the need for robust age models are highlighted with local variation influencing the accumulation of exogenic material. An inter-site comparison suggests enhanced moisture stress regionally during the last glaciation and throughout the LGM, returning to a more positive moisture balance ca. $8 \mathrm{ka}$.
\end{abstract}

Keywords: Geochronology; Optically stimulated luminescence dating; Last Glacial Maximum; Dust; Paleolimnology; Aridity; Optical methods; XRF core scanning; Subtropical

\section{INTRODUCTION}

The last glacial maximum (LGM), which occurred ca. 26.5$19 \mathrm{ka}$ (Clark et al., 2009), remains somewhat poorly understood in Australian late Quaternary paleoenvironmental records (Reeves et al., 2013), despite being an example of a prominent, extreme climate event (Barrows and Juggins, 2005). In the context of the Southern Hemisphere, it has been suggested that the onset of cold and dry climates was earlier (ca. 35-30 ka; Petherick et al., 2011) than the equivalent Northern Hemisphere conditions. The timing of the

Cite this article: Lewis, R. J. et al 2021. Patterns of aeolian deposition in subtropical Australia through the last glacial and deglacial periods. Quaternary Research 102, 68-90. https://doi.org/10.1017/qua.2020.117 climatic shift in the Southern Hemisphere is based on proxy records indicating increased aridity along the eastern margin of Australia (e.g., Colhoun et al., 1999; Kershaw et al., 2007b; Petherick et al., 2008) and internationally (e.g., Denton et al., 1999; Vandergoes et al., 2005). The ensuing LGM was characterized by lowering of sea-level (Grant et al., 2014; Lambeck et al., 2014), reduced precipitation (Hesse et al., 2004), expansion of the continental landmass, and cooler climates across much of the Australian continent (Galloway, 1965; Bowler, 1976; Kemp and Spooner, 2007). However, recent comparative studies of paleoenvironmental records have highlighted the need for robust chronological frameworks because site-specific proxy responses can be complex and hinder deeper understanding of how the LGM influenced the magnitude of environmental change in different regions 
(Harrison, 1993; Turney et al., 2006a; Williams et al., 2009; Reeves et al., 2013).

In order to unravel the complex history of Australian environmental change, it is essential to distinguish between locally driven proxy responses (e.g., change in vegetation cover, fire regimes, topographical influences) and those induced by large-scale shifts in the climate system (Svitok et al., 2011). The challenge is that environmental change may be explained by both local and regional forces; for example, vegetation change may result from local fire regime changes or moisture balance shifts forced by regional climate. Deconvolution between local and regional drivers is important when investigating dust flux as the net mobilization of lithogenic material can be a result of processes at the source (e.g., Washington et al., 2006) and depositional locus (Farebrother et al., 2017). Two ways to separate local and regional signals are to: (1) increase the current multi-proxy paleoenvironmental dataset for the LGM in Australia (Turney et al., 2006a), with particular emphasis on capturing records of sufficient antiquity in underrepresented and climatically sensitive locations; and (2) establish robust chronologies, in combination with multi-proxy datasets, which can be used to infer changes in local variables (e.g., effective precipitation, temperature, catchment conditions, and available moisture) and how they have influenced the paleoenvironmental record.

Lake sediments are important archives of paleoenvironmental information, capable of preserving a multitude of proxies from which, regional, local, and global climate dynamics can be inferred (Reeves et al., 2013). The benefit of lake archives is that they have the capacity to accumulate temporally high-resolution changes through time (Schnurrenberger et al., 2003). However, it is not uncommon for lake sediment records to preserve unconformities due to depositional hiatuses, erosional episodes, or both (Kershaw et al., 2006; Moss and Kershaw, 2007; Mandl et al., 2016). To effectively interrogate paleoenvironmental records from lakes, it is critical to establish an understanding of how lake catchments evolve and how these changes may influence deposition through time (Birks and Birks, 2006). In instances where there is a hiatus in the lake sediment record, the missing information can sometimes be inferred from other associated deposits (e.g., marginal dunes; Fitzsimmons et al., 2007). However, for this approach to be effective, robust age controls are needed for the complementary sedimentary archives (Hesse, 2016).

Many unique biological and geochemical proxies are available within lacustrine sediments, from which physical and chemical analyses can provide insights into environmental change through time. Specific examples of biological proxies often investigated include pollen and charcoal (Kershaw et al., 2010; Ellerton et al., 2017; Lisé-Pronovost et al., 2019; Xiao et al., 2020), diatoms (Gasse and Van Campo, 2001; Song et al., 2020), and stable isotopes of sediments and preserved organisms (Zhang et al., 2011; Long et al., 2018). Analysis of terrigenous particles (e.g., dust) and sedimentary depositional features can be used to evaluate exogenous and in-lake condition changes. Advances in analytical techniques now allow the identification of complex, fine-scale change in sedimentary sequences, including features associated with dust deposition. Moreover, dust characterization from lake records provides a means to trace source locations, thereby providing an important understanding of wind regimes and environmental change in at the source location through time (e.g., McGowan et al., 2008; Petherick et al., 2011).

Identifying changes in lake sediments, particularly those predominantly composed of organic matter, can be challenging because changes in sedimentology may be inconspicuous. In instances when sedimentology is unclear or complex, the application of micro-XRF core scanning ( $\mu \mathrm{XRF}$ ) can provide high-resolution (sub-millimeter) sediment geochemistry without the need for destructive sampling (Croudance and Rothwell, 2015). The success of applying $\mu$ XRF to analyze finely laminated sediment archives has been demonstrated in a range of key paleoenvironmental studies, including climate change (e.g., Kylander et al., 2011; Lauterbach et al., 2011), anthropogenic disturbance (e.g., Guyard et al., 2007; Niemann et al., 2013), identification of pyroclastic material (e.g., Vogel et al., 2010; McCanta et al., 2015), and changes in lake oxygenation conditions (e.g., Davies et al., 2015).

Interpretation of geochemical data obtained using $\mu \mathrm{XRF}$ requires careful consideration, particularly in sediments where composition is highly variable (Boyle, 2002). Lighter elements in particular can be influenced by changes in water and organic content (Tjallingii et al., 2007; Weltje and Tjallingii, 2008), the effects of which can be minimized by normalizing to the total sum of Compton and Rayleigh scatter (incoherent and coherent scatter: inc/coh) (e.g., Kylander et al., 2012; Jouve et al., 2013). Moreover, the setting of the catchment (e.g., local geology and lake-water properties) must be considered when inferring changes in any element quantified using $\mu \mathrm{XRF}$, particularly because post-depositional changes in lake and catchment conditions can influence geochemistry (Kylander et al., 2011).

Geochemical studies from wetlands on North Stradbroke Island show that variations in sediment chemistry are strongly influenced by aeolian influx (e.g., McGowan et al., 2008; Petherick et al., 2009; Kemp et al., 2020; Lewis et al., 2020). Trace element geochemistry of the inorganic sediment fraction from Native Companion Lagoon found the origin of the material was both from the Australian continent, important for providing context during the LGM, and local dunes (McGowan et al., 2008). Subsequent models of aeolian transportation pathways to North Stradbroke Island (Petherick et al., 2009) support this finding, with dust records now improving the understanding of regional climate during the LGM in coastal subtropical Australia (McGowan et al., 2008; Petherick et al., 2011, 2017; Kemp et al., 2020; Lewis et al., 2020).

This study examines environmental changes associated with climate variability since MIS 5 from Brown Lake, North Stradbroke Island, using a combination of geochemistry ( $\mu \mathrm{XRF}$ core scanning) and geochronology (optically 


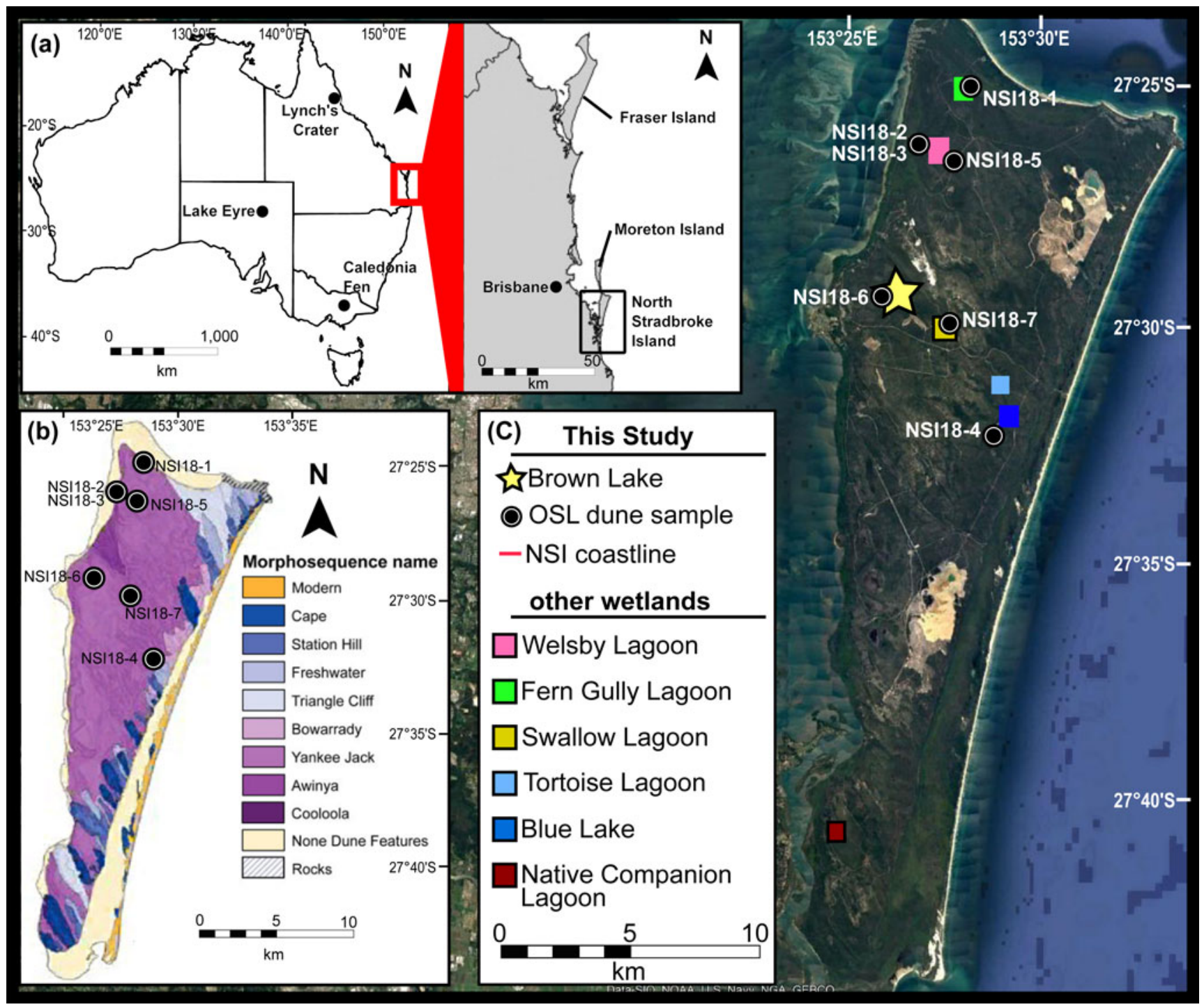

Figure 1. Location of North Stradbroke Island, dune sample sites, and locations referenced in text. (a) Position of the island in relation to Australia, outlined by a red square. (b) Dune field map adapted from Patton et al. (2019), overlain by the OSL sample sites in this study. (c) Satellite image of North Stradbroke Island (source: Google Earth) and the position of wetlands referenced in text. (For interpretation of the references to color in this figure legend, the reader is referred to the web version of this article.)

stimulated luminescence [OSL] and radiocarbon $\left[{ }^{14} \mathrm{C}\right]$ dating). The potential of Brown Lake for improved regional reconstructions of LGM conditions was highlighted by an initial OSL age of $47 \mathrm{ka}$ for the base of the sediment sequence (Tibby et al., 2017). Moreover, there is limited information regarding the timing of dune emplacement proximal to Brown Lake and other wetlands on North Stradbroke Island. The aims of this study are three-fold: (1) to develop the first Bayesian age-depth model for the Brown Lake sediment; (2) to compare dust deposition in Brown Lake with nearby wetlands, to infer the history of late Pleistocene local dust deposition on North Stradbroke Island; and (3) to undertake direct OSL dating of dune fields, which host wetland sediment archives, in order to improve the spatial and temporal coverage of existing paleoenvironmental records for North Stradbroke Island. This will be achieved by examining high- resolution geochemical measurements from cores extracted at two different locations along the longitudinal axis of the water body. The separation between the cores will enable spatial changes attributed to basin evolution to be considered when investigating changes in moisture balance at both local and regional scales.

\section{Study Sites}

North Stradbroke Island is situated $\sim 30 \mathrm{~km}$ east of the city of Brisbane, Queensland and is the second largest sand island in the world (Fig. 1a). North Stradbroke Island is positioned in the subtropics with mean annual summer and winter temperatures between $22-30^{\circ} \mathrm{C}$ and $12-20^{\circ} \mathrm{C}$, respectively (BOM, 2019). The dominant wind direction is the south-east, driven by onshore trade winds (Colls and Whitaker, 1990). Winter 
months on North Stradbroke Island are mild and dry with a large proportion of annual precipitation (1545 mm; BOM, 2019) occurring during the warm, humid summer and autumn seasons.

North Stradbroke Island is part of the extensive south-east Queensland dune system that includes Fraser Island, Moreton Island (Figure 1a), and the Cooloola Sand Mass (Ward, 2006; Patton et al., 2019). The topography of North Stradbroke Island is, in part, determined by the overprinting of older dunes by more recent dune units, becoming younger towards the east coast; as inferred from morphological analysis (Ward, 2006) and remote sensing (Patton et al., 2019) data (Fig. 1b). What remains less clear, however, is what mechanisms are responsible for dune development on North Stradbroke Island, within which numerous wetlands lie (Fig. 1c). This study presents ages for dunes adjacent to prominent wetlands and evaluates the timing of advancement in the context of key climate events, including climate and sea-level change (Grant et al., 2014).

Brown Lake $\left(27^{\circ} 29^{\prime} 10^{\prime \prime} \mathrm{S}, 153^{\circ} 26^{\prime} 01^{\prime \prime} \mathrm{E}\right.$; $56 \mathrm{~m}$ a.s.1.) is a naturally acidic $(\mathrm{pH}=4.85 \pm 0.02$; Mosisch and Arthington, 2001) perched, endorheic lake that lies within the Yankee Jack dune formation (Ward, 2006; Patton et al., 2019). It is the largest lake on North Stradbroke Island and has a 1743 ha drainage basin (Leach, 2011). Brown Lake has a maximum water depth of $8.3 \mathrm{~m}$, which varies in concert with effective precipitation (Fig.2). The present-day vegetation consists of open sclerophyll woodland, with a canopy dominated by Eucalyptus and Allocasuarina (Clifford and Specht, 1979).

\section{METHODS}

\section{Coring and Bathymetry}

Lake sediment cores were extracted from Brown Lake in two expeditions taking place in 2009 and 2018 (Fig. 2). A single, $3.95 \mathrm{~m}$ core was extracted from the central point of the lake in 2009 (BL09) using a Livingstone Corer, capturing $1.0 \mathrm{~m}$ of sediment with each successive drive. Sediment from BL09 was extruded into PVC trays, wrapped in cling film, and transported to the University of Adelaide. In 2011, a bathymetric survey was undertaken using a boat-mounted sonar system (Altimeter: Tritech Int Ltd, Model PA500/6-S) attached to a data recorder (Rugged Brookhouse NMEA 0813) and a GPS (Garmin GPSMAP 60Cx), allowing bottom lake topography to be linked with the core locations. A follow-up coring expedition occurred in 2018, with the aim of acquiring sediment from the northern end of the basin along the 2011 bathymetric transect line (Fig. 2). The two cores were then used to generate a sedimentological profile of Brown Lake and evaluate subsurface heterogeneity. In order to increase the reliability of interpretations from the sediment collected in 2018, two parallel and vertically offset sediment cores (BL18-3 and BL18-4) were collected $2 \mathrm{~m}$ apart using a modified Bolivia piston corer aboard a Kawhaw floating platform. The sediment was extracted in one meter drives, with BL18-3 and BL18-4 reaching depths of $3.57 \mathrm{~m}$ and $2.73 \mathrm{~m}$, respectively. To minimize sediment compaction and exposure to light, each drive was sealed in the core tube rather than being extruded in the field. The cores were split along their longitudinal axis under subdued red LED lighting to prevent daylight contamination and preserve sample integrity for subsequent OSL dating. One half of each core remained under strict lighting conditions (sealed in opaque black plastic) to prevent bleaching of the luminescence signal, while the other was used to conduct further, non-light-sensitive sampling.

\section{Laboratory techniques}

\section{Physical properties of the sediment}

Sediment descriptions were defined using standardized sedimentological terminology and characteristics based on analyzing the sediment both in the core and as a smear, where possible. Sediment properties (i.e., water content, bulk density, and the organic:inorganic ratio) were measured using loss on ignition (LOI) and evaluated at centimeter scale down the length of BL18-3 $(n=347)$. BL09 LOI samples were taken every two centimeters $(n=217)$. Samples were extracted as $1 \mathrm{~cm}^{3}$ of bulk sediment and measured following Heiri et al. (2001). This included weighing sediment before and after oven drying at $100^{\circ} \mathrm{C}$ and ashing at $550^{\circ} \mathrm{C}$.

\section{$\mu X R F$ core scanning}

Geochemical analysis was undertaken using a $\mu$ XRF core scanner, measuring at millimeter resolution, at the Australian Nuclear Science and Technology Organisation (ANSTO) facility (see Supplementary Information for details). Elements of interest for this study were selected using the following criteria: (1) element ratios and element count data from $\mu \mathrm{XRF}$ scanning that represented chemical variation resulting from biogenic productivity $(\mathrm{Ca} / \mathrm{Ti}, \mathrm{Br}, \mathrm{Ca}$, inc/coh, $\mathrm{Si} / \mathrm{Ti})$ and siliciclastic influx ( $\mathrm{Rb}, \mathrm{Al}, \mathrm{Si}, \mathrm{K}, \mathrm{Ze}, \mathrm{Fe}, \mathrm{Ti})$ from within the sediment matrix were targeted (Hendy et al., 2015); (2) elements with large systematic uncertainties (e.g., influenced by the air gap between the sensor and the sediment) were removed from the dataset; and (3) elements and elemental ratios were categorized as intrinsic organic production indicators and extrinsically aeolian-derived lithic indicators-given that Brown Lake is a perched lake with no inflowing streams, sediment accumulation is a function of both. A principal component analysis (PCA) was undertaken on the selected suite of elements, which identified the inorganic component, represented by Axis 1 (PC1), as the major factor of sediment chemical composition (Supplementary Fig. S1). The statistical link between siliciclastic accumulations and element variation enabled direct comparisons with the nearby Fern Gully Lagoon and Welsby Lagoon (Fig.1c) sediment records where aeolian-derived material is a primary influence on sediment chemistry (Kemp et al., 2020; Lewis et al., 2020).

\section{Core correlation}

To overcome artificial breaks resulting from the coring process itself, the parallel and vertically offset cores BL18-3 


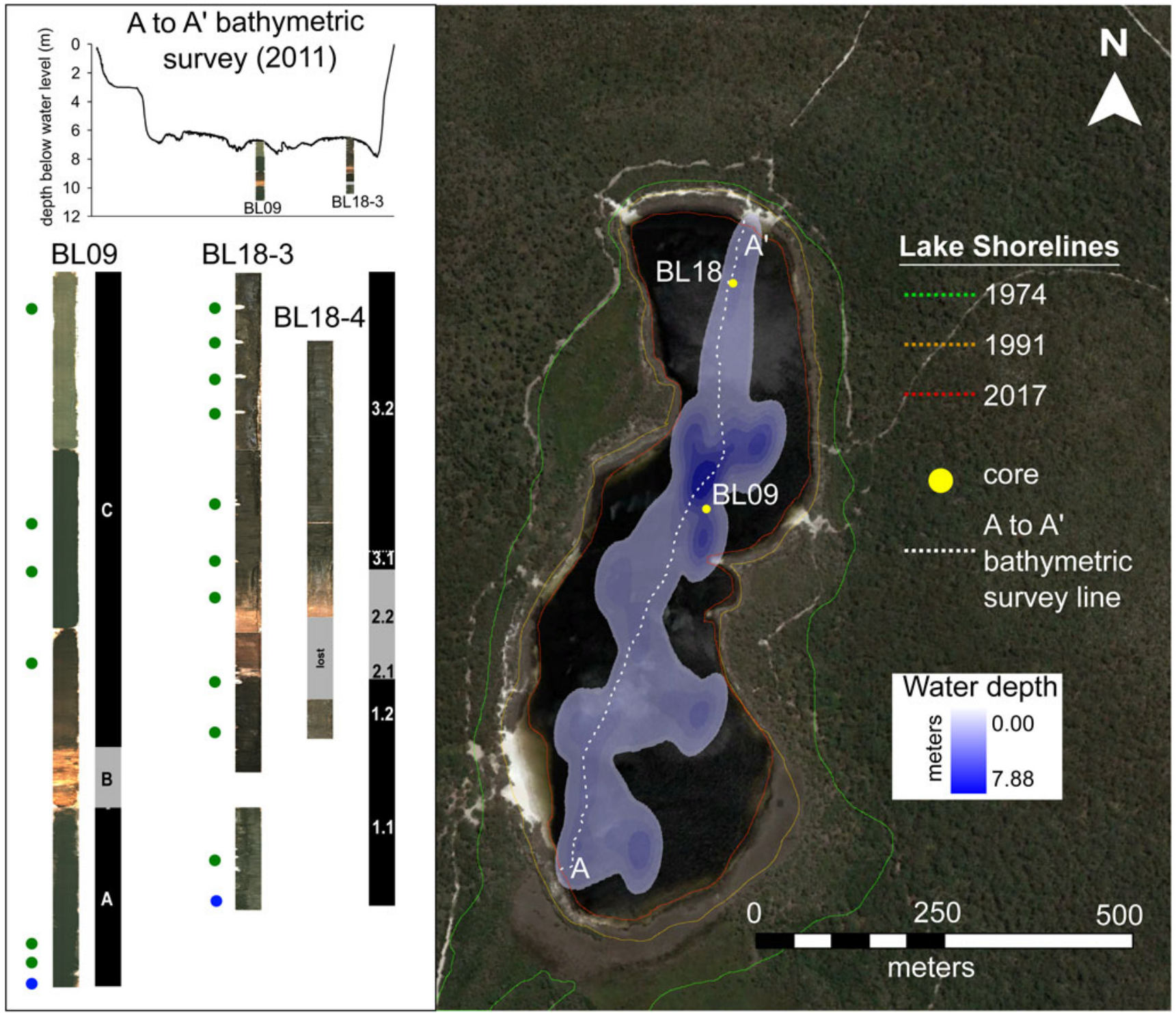

Figure 2. Position of sediment cores BL18 and BL09 recovered from Brown Lake. BL18 and BL09 cores placed on a 2011 bathymetric transect of Brown Lake. Optical images of BL18 and BL09 are shown next to position of radiocarbon samples (green circles), OSL samples (blue circles), and stratigraphic units (black and grey rectangles). Lake shorelines shown on the Google Earth satellite image were identified using historic aerial photos presented in Supplementary Figure S9. (For interpretation of the references to color in this figure legend, the reader is referred to the web version of this article.)

and BL18-4 were combined using sequence slotting, hereafter denoted BL18. Sequence slotting was undertaken in CPLslot v2.4 (Hounslow and Clark, 2016) using the $\mu \mathrm{XRF}$ values for $\mathrm{Al}, \mathrm{Si}, \mathrm{Ca}$, and $\mathrm{Br}$ as input variables. These elements provided accurate estimates of detrital and biochemical input based on their positions and grouping on the PC1 axis for Brown Lake (Supplementary Fig. S1) and other sites on North Stradbroke Island (e.g., Kemp et al., 2020; Lewis et al., 2020). Element count data were normalized by inc/ coh because this was found to correlate with measured LOI values $\left(r^{2}=0.90 ; p\right.$-value <0.05) (Supplementary Fig. S2), thus reducing the influence of water content and, or, organic matter on geochemistry.

The sequence slotting procedure included the following constraints: (1) the combined sequence started with the top of BL18-3; (2) the combined sequence ended with the bottom of BL18-3; and (3) BL18-4 was vertically offset from the surface by at least $0.5 \mathrm{~m}$, and therefore did not overlap with BL18-3 above this depth. Additionally, a series of minor user choices were included in the sequence-slotting algorithm to accommodate the physical characteristics of the sediment in each core (i.e., sediment was lost between $2.02-2.50 \mathrm{~m}$ during retrieval of BL18-4 drive 2-likely a result of increased porosity at the base of the drive relative to BL18-3).

The BL09 and the BL18 cores were not correlated using sequence-slotting because of lithological differences in the sediment profiles (i.e., the presence of a large sand band in the BL18 cores, which was absent in BL09) and the distance between the two coring locations (Fig. 2). Therefore, comparisons between the BL18 and BL09 cores were based on 
stratigraphic similarities and were used primarily to interpret lake history and the extent of heterogeneous sedimentation along a basin transect.

\section{Dating and age modeling}

Radiocarbon dating was undertaken on the BL18-3 and BL09 profiles (Fig. 2) with measurements made on bulk sediment $\left(2 \mathrm{~cm}^{3}\right)$ due to a lack of macrofossils. Eleven bulk sediment samples from BL18-3 were analyzed at the ANSTO Accelerator Mass Spectrometry (AMS) facility, and six samples from BL09 were analyzed at Beta Analytic and the Waikato Radiocarbon Dating Laboratories. The samples were prepared using conventional approaches (see Supplementary Information for details), including standard ABA treatments (Brock et al., 2010). The ${ }^{14} \mathrm{C}$ ages were calibrated to calendar years using OxCal v4.3.2 and the SHCal13 calibration curve (Bronk Ramsey, 2009; Hogg et al., 2013).

Single-grain OSL dating was undertaken on quartz grains from a sample extracted from the base of BL18-3.3 and compared with the single-grain OSL age reported previously for BL09 (Tibby et al., 2017). An additional seven OSL samples were collected from the crest of dunes found adjacent to five prominent North Stradbroke Island wetlands (Fig. 1c). These dune samples were taken from areas with surface exposures classified as the Yankee Jack Formation (Ward, 2006). Three OSL samples were collected from two different dune crests surrounding Welsby Lagoon in order to better constrain variability in dune emplacement and preservation dynamics.

The Brown Lake core sample was extracted under subdued red light conditions, with care taken to ensure contaminant grains from coring were not included in the final analysis, $\sim 1 \mathrm{~cm}$ of sediment was removed from the exposed sediment core face, with sediment within $1 \mathrm{~cm}$ of the coring tube also excluded (this material was retained for dosimetric analysis). The dune samples were collected from freshly dug pits to enable three-dimensional assessments of stratigraphy and ensure that zones affected by extensive root systems and bioturbation were avoided. Dune crests were targeted to maximize the likelihood of sampling primary (non-reworked) aeolian deposits. Individual OSL samples were collected by hammering opaque PVC tubes into cleaned exposures of A2 and B Horizons at depths of $70-180 \mathrm{~cm}$ beneath the surface, taking care to avoid the modern root layer and active bioturbation zones (Supplementary Fig. S3). Approximately $500 \mathrm{~g}$ of additional bulk sediment was collected from the walls of each OSL sample hole (i.e., the surrounding $\sim 2-3 \mathrm{~cm}$ of material in all directions) for evaluation of beta dose rate, secular equilibrium, and water content.

The environmental dose rates of the dune samples have been calculated using a combination of in situ field gamma-ray spectrometry and low-level beta counting. Gamma dose rates were determined from in situ measurements made using a Canberra $\mathrm{NaI}: \mathrm{Tl}$ detector to account for any spatial heterogeneity in the surrounding ( $\sim 30 \mathrm{~cm}$ diameter) gamma radiation field of each sample. The 'energy windows' approach described in Arnold et al. (2012) was used to derive individual estimates of U, Th, and $\mathrm{K}$ concentrations from the field gamma-ray spectra. External beta dose rates were determined from measurements made using a Ris $\varnothing$ GM-25-5 beta counter (Bøtter-Jensen and Mejdahl, 1988) on dried and homogenized, bulk sediments collected directly from the OSL sampling positions. Highresolution gamma spectrometry was additionally performed on the dune samples to examine the state of secular equilibrium in the ${ }^{238} \mathrm{U}$ and ${ }^{232} \mathrm{Th}$ decay series.

Elemental concentrations and specific activities were converted to dose rates using accepted conversion factors (Guérin et al., 2011). A small, assumed internal (alpha plus beta) dose rate component of $0.02 \pm 0.01 \mathrm{~Gy} / \mathrm{ka}$ has been included in the final dose rate calculation based on ICP-MS U and Th measurements made on etched quartz grains from nearby Welsby Lagoon (Lewis et al., 2020) and an alpha efficiency factor of $0.04 \pm 0.01$ (Rees-Jones, 1995; Rees-Jones and Tite, 1997) Cosmic-ray dose rates were calculated (Prescott and Hutton, 1994), after taking into consideration lake water level, site altitude, geomagnetic latitude, and density and thickness of sediment overburden.

The final dose rates for the lake core and dune OSL samples have been corrected for beta-dose attenuation and long-term water content (Mejdahl, 1979; Aitken, 1998; Brennan, 2003). The long-term water content for the Brown Lake OSL sample was considered to be equivalent to the empirical values determined as part of the LOI procedures, with separate corrections applied to the beta, gamma, and cosmic dose rate terms (see Supplementary Table S1 for details). An assumed long-term water content of $7 \pm 3 \%$ was applied to the NSI18 dune samples, following approaches used in comparable OSL dating studies of dune deposits from the region (e.g., Ellerton et al., 2020).

Purified quartz grains ( $\varnothing 180-212 \mu \mathrm{m}$ or $212-250 \mu \mathrm{m}$ ) were prepared using procedures described in Lewis et al. (2020), with single-grain equivalent dose $\left(D_{e}\right)$ measurements undertaken using apparatus and conditions detailed in the Supplementary Information. Single-grain $D_{e}$ values were determined using the single aliquot regenerative dose (SAR) procedure (Murray and Wintle, 2000), shown in Supplementary Table S2. Individual $\mathrm{D}_{\mathrm{e}}$ values were only included in the final age calculation if they satisfied a series of widely accepted quality assurance criteria (Supplementary Table S3).

Bayesian age-depth models were produced for BL18 and BL09 cores in OxCal (Bronk Ramsey, 2009; Bronk Ramsey and Lee, 2013), following the procedures outlined in Lewis et al. (2020) and discussed in the Supplementary Information. Separate depositional units have been included in the OxCal models for BL18 and BL09 on the basis of independent sedimentological and lithological interpretations (as detailed in the Results).

Brown Lake's sedimentological history, and the climate implications influencing deposition with respect to other North Stradbroke Island and Australian records, is discussed in relation to a subset of the eight phases identified through the OZ-INTIMATE climate synthesis (Reeves et al., 2013). We have combined the early and late deglacial phases and considered the Holocene as a whole (Reeves et al., 2013). 


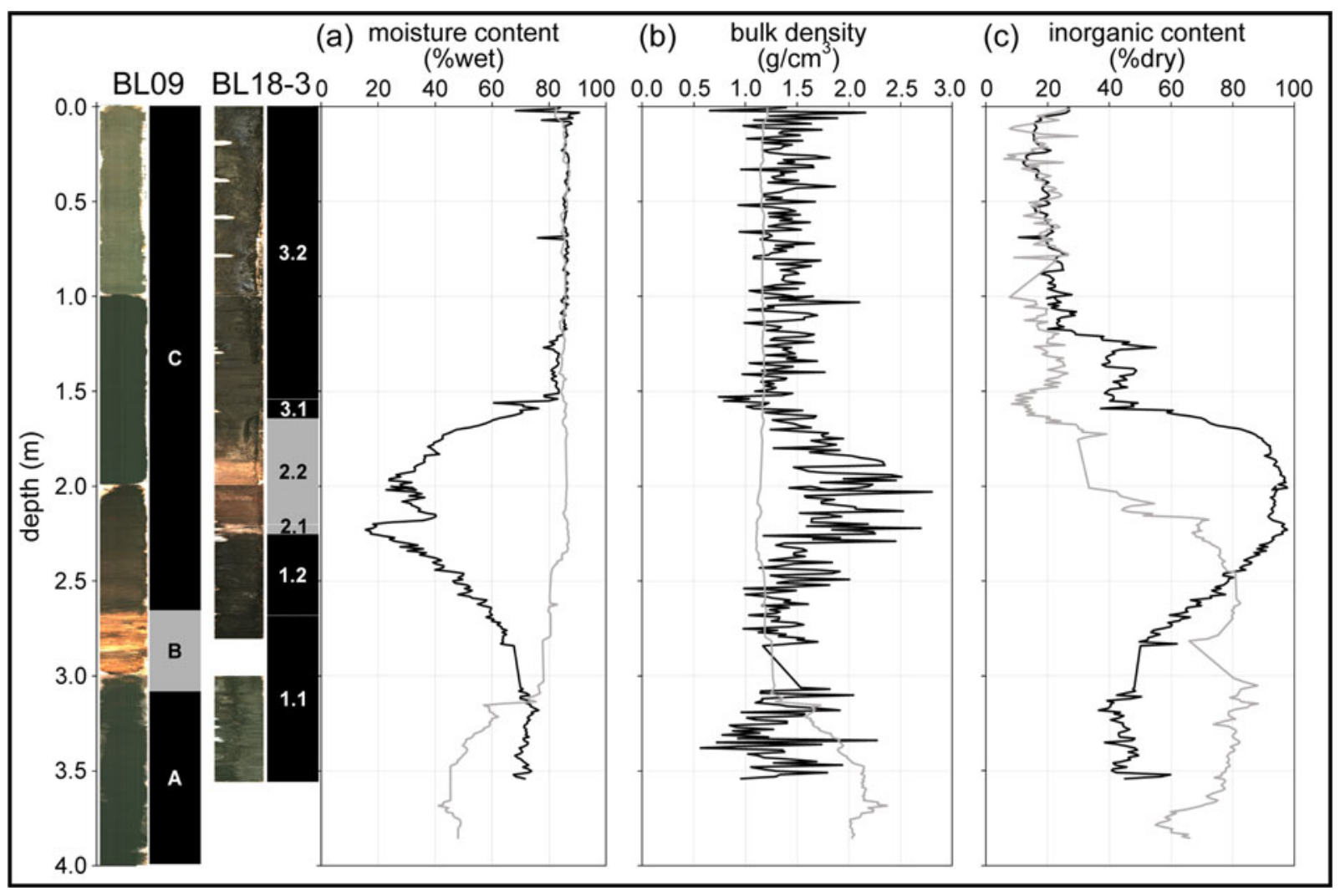

Figure 3. (color online) Optical images, sedimentary units, and properties of BL18 (black) and BL09 (grey) as measured using the loss on ignition approach. Graphs are aligned by depth and show sediment (a) moisture content, (b) bulk density, and (c) inorganic content.

\section{RESULTS}

\section{Lithology, physical and chemical properties}

\section{Sedimentology}

The sediment units present in the BL18 (based on descriptions of BL18-3) and BL09 cores (Fig. 3) are broadly similar and are dominated by very dark-brown to black lake mud with fine- to coarse-grained sands incorporated within the sedimentary matrix. BL18 contains three distinct units, Unit 1 (3.57-2.29 m), Unit $2(2.29-1.65 \mathrm{~m})$, and Unit 3 (1.65-0 $\mathrm{m})$, each of which contains two sub-units. BL09 also contains three units denoted Unit A (3.98-3.14 m), Unit B (3.14-2.67 $\mathrm{m})$, and Unit C (2.67-0 m) (Moss, 2013).

The lowest units present in both cores (Unit 1 and Unit A; Fig. 3) are very dark-brown to black mud (10YR 2/2, 10YR 2/ 1) with a blocky texture. In the BL18 core, sub-unit 1.1 (3.57$2.69 \mathrm{~m}$ ) gradually becomes increasingly pliable towards the top of the unit. Sub-unit $1.2(2.69-2.29 \mathrm{~m})$ is distinguished by a transition from clay to more silty texture and an increased abundance of fine-grained sand. Additionally, this unit also hosts a thin (4 $\mathrm{mm}$ wide) coarse-grained sand vein that is perpendicular to the bedding for $\sim 20 \mathrm{~cm}$ from the top of the unit.

In the BL18 core, Unit 2 is distinguished from Unit 1 by an overall increase in the proportion of sand. The base of the unit is identified by the presence of a distinctive thin $(6 \mathrm{~cm})$, coarse-grained sand layer that contains intermixed angular black clasts $(<1 \mathrm{~mm})$ and light brown grains (Fig. 3) from $2.29 \mathrm{~m}$. A distinctive contact with the underlying sub-unit 1.2 is identified by the juxtaposition of the grey-white sand (10YR 7/1) overlying very dark brown mud (7.5YR 2.5/2). This sand layer is designated sub-unit $2.1(2.29-2.23 \mathrm{~m})$ and is only present in the BL18 record. The shared sedimentology between BL18 and BL09 is re-established from subunit $2.2(2.23-1.65 \mathrm{~m})$ and Unit B $(3.14-2.67 \mathrm{~m})$ upwards (Fig. 3). The sedimentology of these units both increase in clay content up core with a decrease in the proportion of sand grains towards the surface more apparent in BL18. The sediment changes from the grey-white sand of sub-unit 2.1 into a dark brown (10YR 3/2) towards the middle, before grading into a black mud (10YR 2/1) towards the top. However, the color gradient is not as obvious in BL09, due to the as the absence of the underlying sandy layer.

The youngest, and thickest unit in the BL18 and BL09 cores is Unit $3(1.65-0 \mathrm{~m})$ and Unit $\mathrm{C}(2.67-0 \mathrm{~m})$, respectively (Fig. 3). The base of this unit in BL18 is designated sub-unit $3.1(1.65-1.55 \mathrm{~m})$, which is characterized by the sediment having had transitioned from the mud of sub-unit 2.2 to a more organic-rich, silty clay-like texture. This subsequently transitions into the homogenous organic black (10YR 2/1) mud of sub-unit $3.2(1.55-0 \mathrm{~m})$. The change in texture between sub-unit 3.1 and 3.2 is concordant with the incorporation of very fine-grained sand material within the sediment matrix towards the top of Unit 3 . 


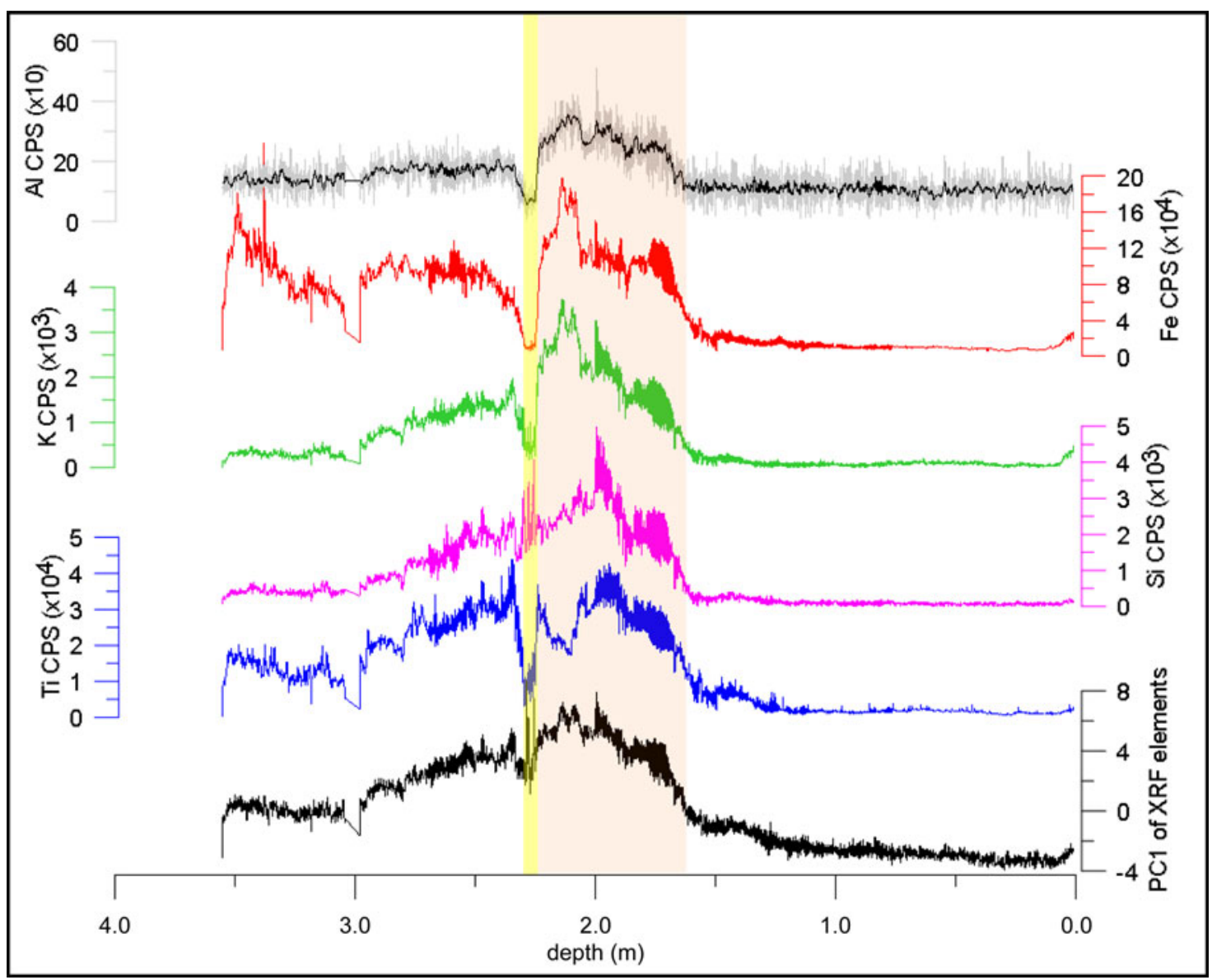

Figure 4. Scanning XRF elemental counts per second (CPS) of selected terrigenous elements (as identified using Principal Component Analysis). Aluminum elemental counts (grey line) overlain by a 10 point moving average (black line). Yellow and orange shading represent the sand (sub-unit 2.1) and transitional (sub-unit 2.2) layers observed in the BL18 sedimentary sequence, respectively. For biogenic element correlations the reader is directed to Supplementary Figure S8. (For interpretation of the references to color in this figure legend, the reader is referred to the web version of this article.)

\section{Moisture and organic content}

The moisture and organic content of the BL18 and BL09 records reflect the sedimentary unit divisions (Fig. 3). The sediment from BL18 has a wider range of moisture content $\left(15.5-90.6 \%_{\text {wet }}\right)$, bulk density $\left(0.5-2.8 \mathrm{~g} / \mathrm{cm}^{3}\right)$, and inorganic content $\left(10.5-97.7 \%_{\text {dry }}\right)$ than BL09 $\left(41.1-87.2 \%_{\text {wet }}\right.$; $1.1-2.4 \mathrm{~g} / \mathrm{cm}^{3} ; 5.7-88.2 \%$ dry ). Our analysis of these properties focusses on BL18 because this core sequence would have experienced less physical alteration during the core extraction in comparison to BL09, which was extruded in the field.

Unit 3 of BL18 has the highest moisture content of the three units of the same core, with a mean value of $\sim 84 \%$ (Unit 2 and Unit 1 have mean values of $36 \%$ and $61 \%$, respectively). Unit 2 has the highest inorganic content on average $\left(91 \%_{\text {dry }}\right)$, which is more than double that of Unit 3 $(26 \%$ dry $)$ and higher than Unit $1\left(59 \%_{\text {dry }}\right)$. The sandy Unit 2 has a mean bulk density of $1.8 \mathrm{~g} / \mathrm{cm}^{3}$, which was considerably higher than that of Unit 3 and Unit 1 (both have an average of $1.4 \mathrm{~g} / \mathrm{cm}^{3}$ ). This difference in bulk density likely reflects the influence of increased inorganic material having been deposited within the soil matrix of Unit 2 .

\section{$\mu X R F$ elemental scanning and principal component analysis}

The elemental counts from the $\mu$ XRF core scanning of BL18 and BL09 exhibit amplitude changes that correspond with transitions between sedimentary units (Fig. 4, Supplementary Fig. S7). $\mu \mathrm{XRF}$ Rayleigh scattering (i.e., incoherent/ coherent) had a strong correlation $\left(r^{2}=0.95\right.$, p-value $<0.05$; Supplementary Fig. S2) with organic matter content as determined by LOI. Elements of interest (see Methods) were subsequently incorporated into a PCA to evaluate their variability down core. Elements associated with clastic terrestrial origins had high loadings on PC1 (Supplementary Fig. S1). Additionally, the correlation between these elements (Supplementary Fig. S1) suggests that the sediment chemistry is strongly influenced by the influx of aeolian transported inorganic material, as observed in neighboring organic-rich 
Table 1. Radiocarbon $\left({ }^{14} \mathrm{C}\right)$ ages for the samples extracted from BL18 and BL09 Brown Lake sediment cores, respectively. Ages have been calibrated against SHCal13 using the OxCal software (Bronk Ramsey, 2009; Bronk Ramsey and Lee, 2013; Hogg et al., 2013). All samples were treated using acid-base-acid (ABA) pre-treatments. The calibrated age range shown is the $95.4 \%$ probability range (combining two or more potential calibration ranges, where they exist).

\begin{tabular}{|c|c|c|c|c|c|c|}
\hline Lab Code & Depth $(\mathrm{cm})$ & Material & $\delta 13 \mathrm{C}$ & $\begin{array}{c}\text { Conventional }{ }^{14} \mathrm{C} \\
\text { age }\left({ }^{14} \mathrm{C} \text { yr BP }\right)\end{array}$ & Uncertainty $(1 \sigma)$ & $\begin{array}{c}\text { Calibrated age } \\
\text { range }(\text { cal yr BP) }\end{array}$ \\
\hline OZX784 & 20 & Lake Sediment & -29.1 & 640 & 20 & $640-550$ \\
\hline OZX785 & 43 & Lake Sediment & -28.3 & 1430 & 25 & $1350-1270$ \\
\hline OZX786 & 62 & Lake Sediment & -33.8 & 2130 & 25 & $2150-2000$ \\
\hline OZX787 & 80 & Lake Sediment & -29.6 & 3100 & 25 & $3360-3180$ \\
\hline OZX788 & 130 & Lake Sediment & -29.6 & 5570 & 30 & $6400-6280$ \\
\hline OZX789 & 163 & Lake Sediment & -27.6 & 7120 & 30 & $7980-7840$ \\
\hline OZX790 & 183 & Lake Sediment & -27.3 & 16,660 & 70 & $20,310-19,790$ \\
\hline OZX791 & 230 & Lake Sediment & -27.9 & 36,570 & 290 & $41,790-40,430$ \\
\hline OZX792a & 258 & Lake Sediment & -28.0 & 43,770 & 490 & $48,790-45,620$ \\
\hline OZX793 ${ }^{\mathrm{a}}$ & 258 & Lake Sediment & -26.6 & 44,870 & 410 & $49,830-46,710$ \\
\hline OZX794a ${ }^{b}$ & 330 & Lake Sediment & -28.0 & 34,970 & 220 & $40,110-38,790$ \\
\hline OZX794b ${ }^{b}$ & 330 & Lake Sediment & -28.2 & 35,230 & 190 & $40,400-39,070$ \\
\hline Beta-361743 & 21 & Organic Sediment & -29.7 & 540 & 30 & $550-500$ \\
\hline Beta-361744 & 142 & Organic Sediment & -29.9 & 2420 & 30 & $2680-2340$ \\
\hline Beta-361745 & 167 & Organic Sediment & -30.1 & 3310 & 40 & $3590-3390$ \\
\hline Beta-361746 & 219 & Organic Sediment & -25.3 & 6530 & 110 & $7580-7170$ \\
\hline Beta-361748 & 376 & Organic Sediment & -27.6 & 31,980 & 230 & $36,330-35,300$ \\
\hline Wk-33179 & 386 & Organic Sediment & -33.1 & 36,970 & 740 & $42,610-40,130$ \\
\hline
\end{tabular}

${ }^{\mathrm{a}, \mathrm{b}}$ Replicate samples, which were combined in the Bayesian age-depth modelling using the OxCal 'combine' function.

${ }^{\mathrm{c}}$ Rounded to nearest ten years.

wetland sediments (Kemp et al., 2020; Lewis et al., 2020). Geochemical variation driven by inorganic material deposition is further supported by the separate grouping of biogenic and lithogenic element proxies and ratios (Supplementary Fig. S1), particularly the low loading on PC1 for the organic indicator (i.e., inc/coh).

\section{Core correlation}

Sequence-slotting successfully matched the element concentrations from BL18-4 to those in BL18-3, as shown in Supplementary Figure S10. The potential range of sequence-slotting configurations is demonstrated in the H-matrix (Supplementary Fig. S10) (Gordon, 1982) and represents all possible depths at which slotting could occur. For this study, the central correlative depth is taken from the H-matrix to represent the best fit of the two cores thus used to project the depths of BL18-4 onto those of BL18-3. The suitability of using this approach is also supported by the high delta value $(0.828)$, indicating that the sequences were well matched.

\section{Chronology}

\section{${ }^{14} \mathrm{C}$ dating}

The AMS ${ }^{14} \mathrm{C}$ ages obtained for BL18 and BL09 are presented in Table 1. Overall, there is stratigraphic agreement between the ${ }^{14} \mathrm{C}$ results from core BL18 and BL09. Moreover, the ages of replicate samples collected from the same depth in the BL18 core (OZX792/OZX793) overlap at $1 \sigma$. The ${ }^{14} \mathrm{C}$ sample extracted from the bottom of the BL18 core (OZX794a) produced a 95.4\% C.I. calibrated age range of 40,120-38,790 cal yr BP, which was confirmed with a replicate measurement $(\mathrm{OZX794b}=40,400-39,070 \mathrm{cal}$ yr BP $)$. The ${ }^{14} \mathrm{C}$ ages for this sample are systematically younger than the overlying replicate samples (OZX792, OZX793), which yielded replicate $95.4 \%$ C.I. calibrated age range of 48,790-45,620 cal yr BP and 49,830-46,710 cal yr BP, respectively. The cause of the inversion is currently uncertain and is possibly linked to sediment mixing from turbulence, humification, or both (Shore et al., 1995).

\section{OSL dating}

The results of the single-grain OSL $\mathrm{D}_{\mathrm{e}}$ analysis and age determination are reported in Table 2 and Figure 5. The acceptance rate of grains for each OSL sample, following application of the SAR quality assurance criteria, ranged between 2-8\% (Supplementary Table S3). Most samples (5 out of 8 ) exhibit relatively homogeneous single-grain $D_{e}$ distributions with low overdispersion values of $18-20 \%$. These overdispersion values are consistent with those typically reported for well-bleached and undisturbed single-grain $D_{e}$ datasets at $2 \sigma$ (e.g., the average overdispersion of $20 \pm 1 \%$; Olley et al., 2004; Arnold and Roberts, 2009), as well as those reported for 'ideal' lacustrine samples from related North 


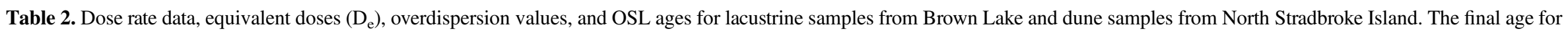

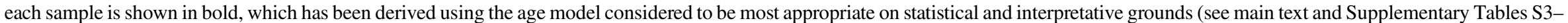
S6 for details).

\begin{tabular}{|c|c|c|c|c|c|c|c|c|c|c|c|c|}
\hline \multirow[b]{2}{*}{ ID } & \multirow{2}{*}{$\begin{array}{c}\text { Wetland } \\
\text { Catchment }\end{array}$} & \multirow{2}{*}{$\begin{array}{l}\text { Depth } \\
(\mathrm{cm})\end{array}$} & \multirow{2}{*}{$\begin{array}{l}\text { Grain Size } \\
(\mu \mathrm{m})\end{array}$} & \multicolumn{3}{|c|}{ Water Content (\%Dry) $^{\mathrm{a}}$} & \multirow{2}{*}{$\begin{array}{l}\text { Total Dose Rate (Gy/ } \\
\text { kyr) b, c }\end{array}$} & \multirow[b]{2}{*}{$\mathrm{n} / \mathrm{N}^{\mathrm{d}}$} & \multirow{2}{*}{$\begin{array}{l}\mathrm{OD} \\
(\%)^{\mathrm{e}}\end{array}$} & \multirow{2}{*}{ Age $\underset{\mathrm{f}}{\text { Model }}$} & \multirow[b]{2}{*}{$\mathrm{D}_{\mathrm{e}}(\mathrm{Gy})^{\mathrm{c}}$} & \multirow{2}{*}{$\underset{\mathrm{c}}{\text { Final }}$ Age $(\mathrm{ka})$} \\
\hline & & & & Gamma & Beta & Cosmic & & & & & & \\
\hline $\begin{array}{l}\text { BL18-A } \\
\text { (BL18) }\end{array}$ & Brown Lake & 353 & $180-212$ & $253 \pm 13$ & $242 \pm 12$ & $340 \pm 17$ & $0.67 \pm 0.04^{\mathrm{e}}$ & $46 / 600$ & $19 \pm 3$ & CAM & $37.1 \pm 1.3$ & $55.6 \pm 4.4$ \\
\hline $\begin{array}{l}\text { GU5.3 }{ }^{\mathrm{g}} \\
\text { (BL09) }\end{array}$ & Brown Lake & 397 & $180-212$ & $24 \pm 2$ & $24 \pm 2$ & $68 \pm 7$ & $0.73 \pm 0.14$ & 66 & 40 & FMM & $32.8 \pm 2.0(94 \%)$ & $45.0 \pm 8.9$ \\
\hline NSI18-1 & $\begin{array}{l}\text { Fern Gully } \\
\text { Lagoon }\end{array}$ & 160 & $212-250$ & $7 \pm 3$ & $7 \pm 3$ & $7 \pm 3$ & $0.33 \pm 0.02$ & $31 / 900$ & $19 \pm 3$ & CAM & $\begin{array}{l}16.3 \pm 2.0(6 \%) \\
\mathbf{3 4 . 5} \pm \mathbf{1 . 4}\end{array}$ & $\begin{array}{r}22.4 \pm 5.0 \\
\mathbf{1 0 4 . 8} \pm \mathbf{8 . 7}\end{array}$ \\
\hline NSI18-2 & Welsby Lagoon & 183 & $212-250$ & $7 \pm 3$ & $7 \pm 3$ & $7 \pm 3$ & $0.41 \pm 0.03$ & $32 / 900$ & $18 \pm 3$ & CAM & $63.5 \pm 2.6$ & $155.4 \pm 11.7$ \\
\hline NSI18-3 & Welsby Lagoon & 150 & $212-250$ & $7 \pm 3$ & $7 \pm 3$ & $7 \pm 3$ & $0.58 \pm 0.03$ & $37 / 900$ & $20 \pm 3$ & CAM & $59.1 \pm 2.2$ & $102.2 \pm 7.6$ \\
\hline \multirow[t]{2}{*}{ NSI18-4 } & Blue Lake & 170 & $212-250$ & $7 \pm 3$ & $7 \pm 3$ & $7 \pm 3$ & $0.30 \pm 0.02$ & $\begin{array}{l}32 / \\
1100\end{array}$ & $46 \pm 7$ & CAM & $50.9 \pm 4.4$ & $167.8 \pm 19.1$ \\
\hline & & & & & & & & & & FMM & $\begin{array}{c}37.0 \pm 9.3(51 \%) \\
70.54 \pm 19.0(49 \%)\end{array}$ & $\begin{array}{l}122.0 \pm 32.0 \\
232.6 \pm 65.0\end{array}$ \\
\hline \multirow[t]{2}{*}{ NSI18-5 } & Welsby Lagoon & 70 & $212-250$ & $7 \pm 3$ & $7 \pm 3$ & $7 \pm 3$ & $1.26 \pm 0.07$ & $\begin{array}{l}32 / \\
1600\end{array}$ & $43 \pm 6$ & CAM & $115.1 \pm 9.5$ & $91.0 \pm 9.1$ \\
\hline & & & & & & & & & & FMM & $\begin{array}{c}77.4 \pm 7.7(49 \%) \\
166.6 \pm 14.5(51 \%)\end{array}$ & $\begin{array}{c}61.2 \pm 7.0 \\
131.7 \pm 13.6\end{array}$ \\
\hline NSI18-6 & Brown Lake & 170 & $212-250$ & $7 \pm 3$ & $7 \pm 3$ & $7 \pm 3$ & $0.35 \pm 0.02$ & $37 / 600$ & $19 \pm 3$ & CAM & $42.1 \pm 1.6$ & $119.4 \pm 9.4$ \\
\hline \multirow[t]{2}{*}{ NSI18-7 } & Swallow Lagoon & 130 & $212-250$ & $7 \pm 3$ & $7 \pm 3$ & $7 \pm 3$ & $0.40 \pm 0.03$ & $\begin{array}{l}55 / \\
1100\end{array}$ & $74 \pm 8$ & CAM & $10.4 \pm 1.1$ & $25.8 \pm 3.2$ \\
\hline & & & & & & & & & & FMM & $\begin{array}{r}4.5 \pm 0.3(36 \%) \\
10.8 \pm 1.0(29 \%) \\
24.2 \pm 1.8(35 \%)\end{array}$ & $\begin{array}{l}11.2 \pm 1.1 \\
26.8 \pm 3.1 \\
60.1 \pm 6.0\end{array}$ \\
\hline
\end{tabular}

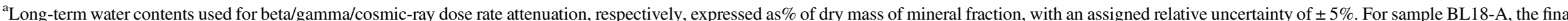

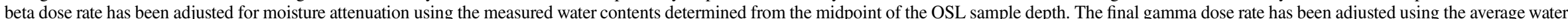

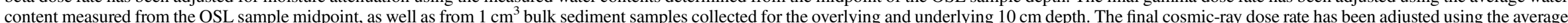

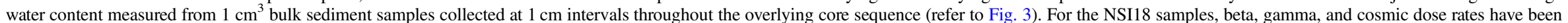
corrected using a fixed long-term water content of $7 \pm 3 \%$, following approaches used in comparable OSL dating studies of dune deposits in the region (e.g., Ellerton et al., 2020).

${ }^{\mathrm{b}}$ Individual dose rate components (i.e., gamma, beta, internal, and cosmic dose rate contributions) are outlined in Supplementary Table S1.

${ }^{\mathrm{c}}$ Mean \pm total uncertainty (68\% confidence interval), calculated as the quadratic sum of the random and systematic uncertainties.

${ }^{\mathrm{d}}$ Number of $\mathrm{D}_{\mathrm{e}}$ measurements that passed the SAR quality assurance criteria and were used for $\mathrm{D}_{\mathrm{e}}$ determination $(\mathrm{n}) /$ total number of grains analyzed $(\mathrm{N})$.

${ }^{\mathrm{e}} \mathrm{OD}=$ overdispersion; the relative spread in the $\mathrm{D}_{\mathrm{e}}$ dataset beyond that associated with the measurement uncertainties for individual $\mathrm{D}_{\mathrm{e}}$ values.

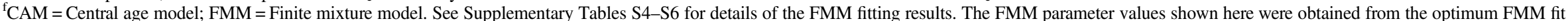

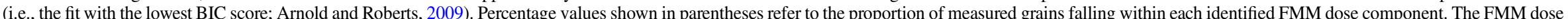
component containing the highest proportion of accepted grains has been nominally selected for the final FMM $\mathrm{D}_{\mathrm{e}}$ calculation; see main text for further discussions and sample-specific interpretations.

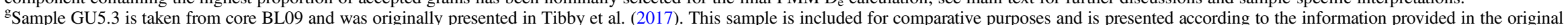
publication. 


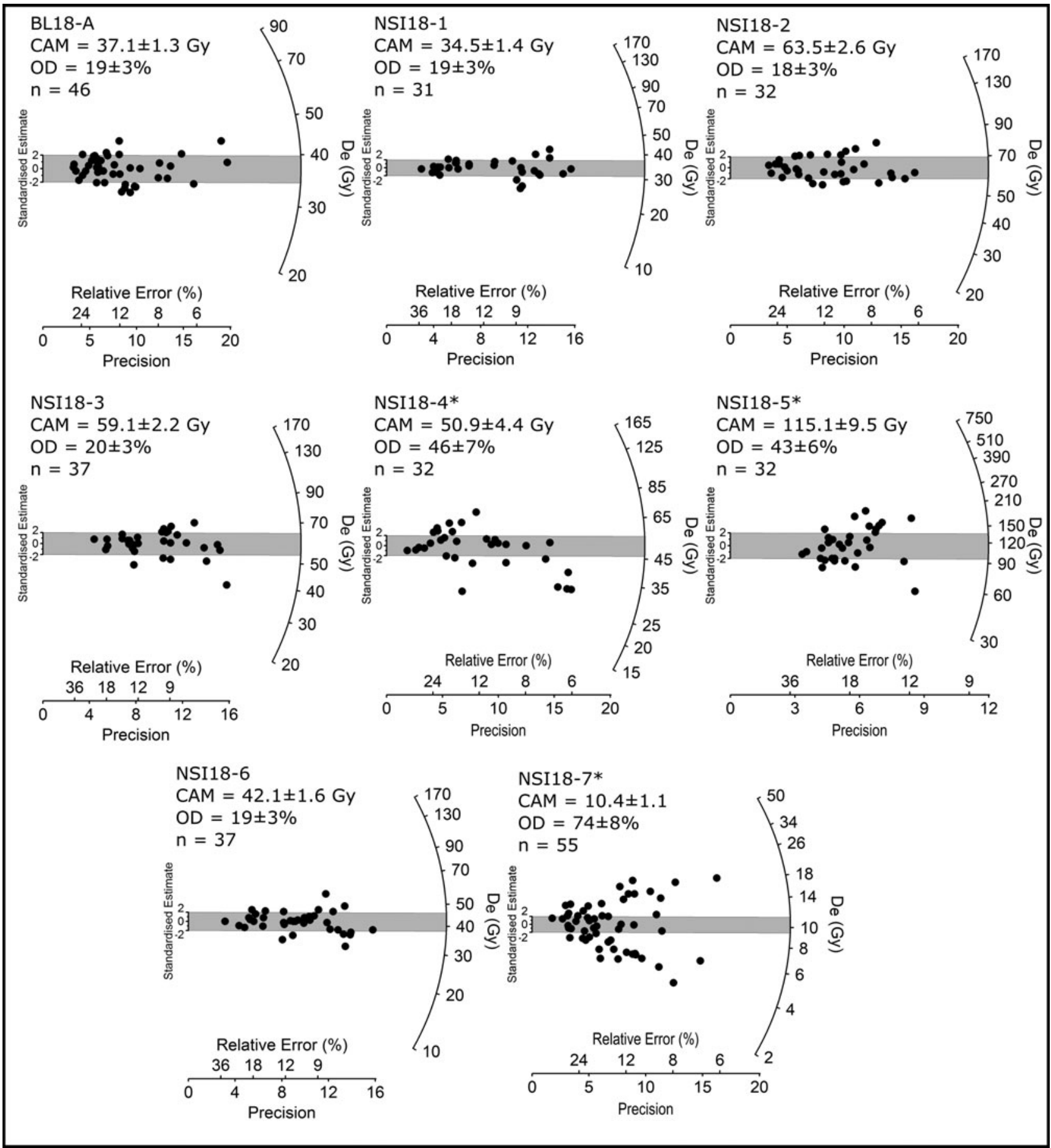

Figure 5. Radial plots showing the single-grain $D_{e}$ distributions obtained for OSL samples from the BL18-3 core and NSI18 dunes. The grey shaded band on each plot is centered on the $D_{e}$ value (in Gy) used for the final age calculation. For all samples, the $D_{e}$ value has been calculated using the central age model (CAM) of Galbraith et al. (1999). For comparative purposes, the finite mixture model (FMM) dose components identified for samples marked with an asterisk $\left(^{*}\right)$ are shown in Supplementary Figure S5b.

Stradbroke Island wetland localities (e.g., Kemp et al., 2020; Lewis et al., 2020). The final $D_{e}$ values of these five samples (BL18-A, NSI18-1, NSI18-2, NSI18-3, and NSI18-6) have therefore been calculated using the central age model (CAM) (Galbraith et al., 1999).

Interestingly, the limited $\mathrm{D}_{\mathrm{e}}$ scatter and low overdispersion obtained for Brown Lake sample BL18-A contrast with the
$D_{e}$ characteristics reported for sample GU5.3 from core BL09 (Tibby et al., 2017), despite being extracted from the same sediment body. Sample GU5.3 has an overdispersion of $40 \%$ (approximately twice that of BL18-A; 19 $\pm 3 \%$ ), which was originally attributed to a combination of sediment disturbance (e.g., Arnold and Roberts, 2011) and insufficient resetting of residual signals prior to burial (e.g., Arnold et al., 
2007; Arnold and Roberts, 2009). Given the homogenous $D_{\mathrm{e}}$ distribution we report for sample BL18-A, an alternative explanation for the GU5.3 $\mathrm{D}_{\mathrm{e}}$ scatter might relate to the coring approach utilized (Tibby et al., 2017). Unlike the BL18 sediment, which was retained within the core tubes, the BL09 core was extruded in the field with limited protection from light exposure. Considering these contrasting sampling approaches, the BL09 sediment may have additionally experienced some vertical grain transfer or light contamination prior to OSL sampling, which could have given rise to a seemingly mixed or heterogeneously bleached $\mathrm{D}_{\mathrm{e}}$ signature (incorporating both low and high $\mathrm{D}_{\mathrm{e}}$ scatter). For the purpose of this study, we have included the originally published age for sample GU5.3 in our site assessment $(45 \pm 8.9 \mathrm{ka}$; Tibby et al., 2017) because it has been derived using a statistical age model designed to account for additional $\mathrm{D}_{\mathrm{e}}$ scatter related to potential sampling contamination (finite mixture model; Galbraith and Green, 1990); although we note potential caveats regarding the original interpretation of this $\mathrm{D}_{\mathrm{e}}$ dataset.

Three of the dune samples (NSI18-4, NSI18-5, NSI18-7) exhibit complex $\mathrm{D}_{\mathrm{e}}$ distributions characterized by broad $\mathrm{D}_{\mathrm{e}}$ scatter and high overdispersion values $(43 \pm 6 \%$ to $74 \pm$ $8 \%$ ) that do not overlap at $2 \sigma$ with the site-specific 'baseline' estimates of underlying dose overdispersion determined from dune samples NSI18-1, NSI18-2, NSI18-3, and NSI18-6. Application of the FMM to these three $\mathrm{D}_{\mathrm{e}}$ datasets also confirms the presence of multiple discrete dose components (Supplementary Tables S4-S6). Similar multimodal and scattered single-grain OSL $D_{e}$ datasets have been reported elsewhere for the Cooloola Sand Mass (Walker et al., 2018), and have been interpreted as reflecting aeolian reactivation and localized reworking of original dune emplacements. This type of post-depositional mixing, whereby pre-existing aeolian deposits are incorporated into more recent dune building events, could be considered a possible explanation for some of the discrete dose components observed in samples NSI18-4, NSI18-5, and NSI18-7. However, given the low dose rates of these quartz-rich dune sands (Table 2), and the known presence of heavy minerals (zircons, monazites) and K-feldspar grains that could have acted as radioactivity hotspots in the Yankee Jack Formation (Thompson, 1981; Tejan-Kella et al., 1990), it is feasible that this enhanced dose dispersion could have arisen from spatial variations in beta dose rates experienced by individual grains (e.g., Nathan et al., 2003). Intrinsic sources of $D_{e}$ scatter (e.g., Demuro et al., 2013) or bioturbation could have further contributed to the observed scatter in these three samples; though it is notable that such complications were not similarly observed in the other samples from these sites that displayed ideal $\mathrm{D}_{\mathrm{e}}$ distributions (NSI18-1, NSI18-2, NSI18-3, and NSI18-6).

The difficulties of ascertaining the true underlying sources of $D_{e}$ scatter for NSI18-4, NSI18-5, and NSI18-7, and the impracticalities of retrospectively calculating suitable dose rates for the identified multiple dose components, mean that use of the FMM for OSL age evaluation is not necessarily straightforward in this study. These interpretive complications are compounded by the fact that the identified components of each sample contain very similar proportions of grains (i.e., there are no clear dominant dose components). As a pragmatic solution, we have therefore used the CAM $\mathrm{D}_{\mathrm{e}}$ and bulk (sample-averaged) dose rate to derive the final age estimates for NSI18-4, NSI18-5, and NSI18-7 (Table 2). For comparative purposes, Table 2 also shows the ages derived for these samples using the FMM components, assuming that the sample-averaged dose rates are broadly representative of those experienced by individual dose components during burial. This assumption may be reasonable given the shared local source of accumulated sediment in a given dune field, but further research would be required to demonstrate its suitability for the individual deposits under consideration here.

The CAM ages for samples NSI18-4 and NSI18-5 are broadly consistent (at $2 \sigma$ ) with those obtained for the well-bleached and unmixed samples from the Yankee Jack Formation (Table 2). However, the CAM age for NSI18-7 is significantly younger than those obtained at our other dune study sites, as well as those published previously by Walker et al. (2018) and Ellerton et al. (2020). Reliable interpretation of NSI18-7 is complicated by the identification of three discrete FMM dose components, and we cannot discount the possibility that this sample has been compromised by significant post-depositional sediment mixing or disturbances related to recent human activity (e.g., forestry operations; Walker et al., 2018).

\section{Lake sequence age modeling}

The Bayesian age-depth models for the Brown Lake sedimentary sequences, as produced using OxCal v4.3.2 (Bronk Ramsey, 2017), are shown in Figure 6. The likelihood estimates of the BL18 and BL09 sediment cores are constrained by two single-grain OSL ages (BL18-A and GU5.3, respectively) and a combined total of sixteen ${ }^{14} \mathrm{C}$ ages. A preliminary version of the BL18 age-depth model included the replicate OZX94a and OZX94b ${ }^{14} \mathrm{C}$ ages. However, the modeled likelihood estimates failed to converge, with these two samples identified as statistical outliers (79\%) owing to their incompatibility with the surrounding OSL (BL18-A) and ${ }^{14} \mathrm{C}$ ages (OZX793 and OXZ792). As such, these two major outliers were not included in the final Bayesian age-depth model for BL18.

The BL18 and BL09 Bayesian models have agreement index $\left(\mathrm{A}_{\text {model }}\right)$ values of $100.4 \%$ and $101.2 \%$, respectively, and overall agreement index $\left(\mathrm{A}_{\text {overall }}\right)$ values of $99.9 \%$ and $100.6 \%$, respectively - all above the minimum threshold of $60 \%$ (Bronk Ramsey, 2009). The outlier analysis of BL09 identified Beta-361743 as having a relatively high posterior probability of $22 \%$. In core BL18, there were no samples that had exceptionally high posterior outlier probabilities (Fig. 6), with combined ${ }^{14} \mathrm{C}$ samples OZX793/OZX792 identified as having low outlier probability of $8 \%$. The modeled boundary ages and use of the OxCal Difference query (see Supplementary Information) show for the lowermost BL09 unit (Unit A) and equivalent BL18 unit (Unit 1) that 

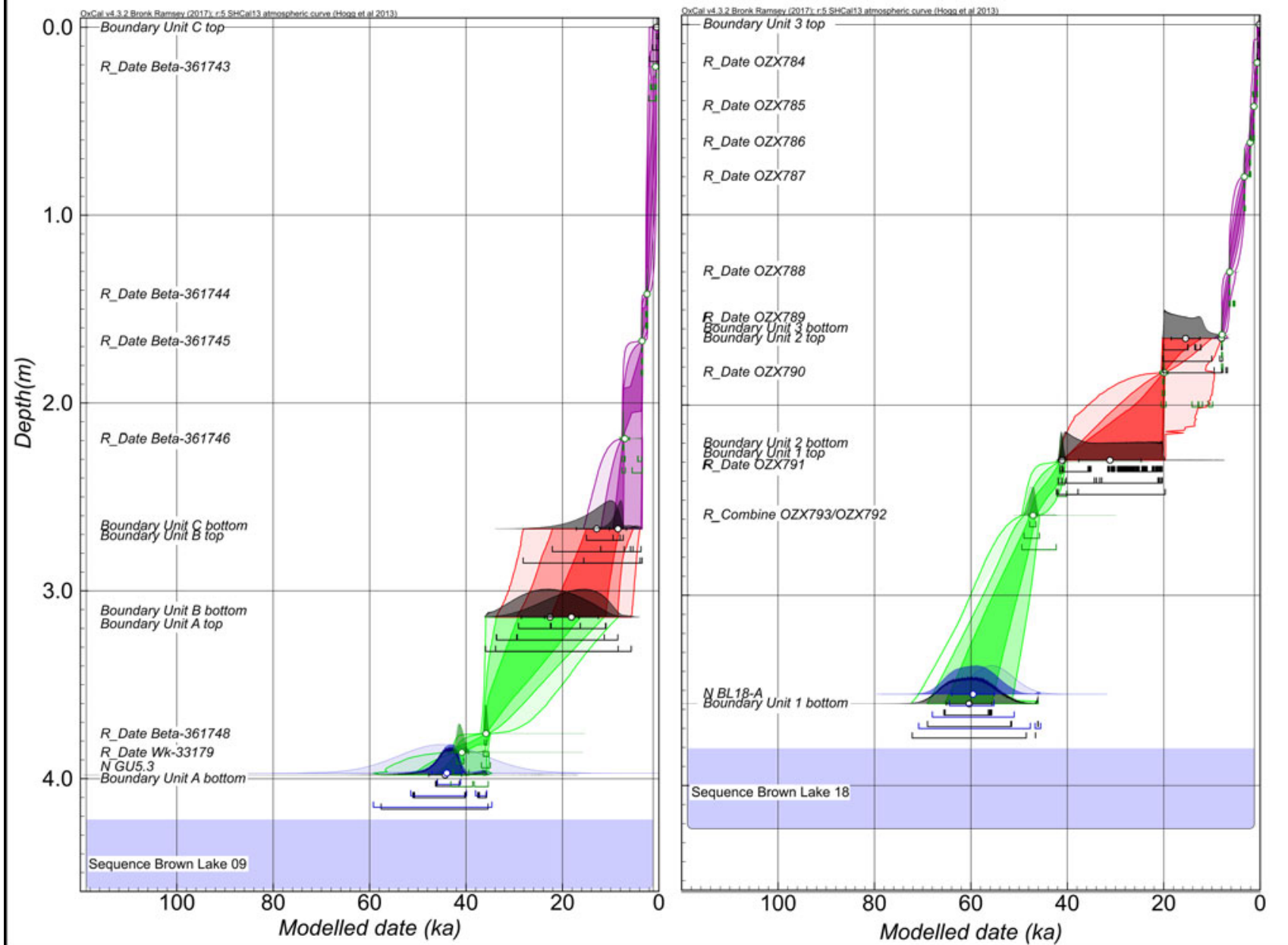

Figure 6. Bayesian age-depth model constructed in OxCal version 4.3.2 using the single-grain OSL and ${ }^{14} \mathrm{C}$ ages obtained for the BL09 (left) and BL18 (right) cores. The original probability distributions for the OSL (blue) and ${ }^{14} \mathrm{C}$ (green) age estimates (the likelihoods) and the posterior modeling distributions are represented as light and dark shading of the respective colors. The age-depth model envelopes show the $99 \%$, $95 \%$, and $68 \%$ highest probability density ranges for each of the main depositional units (green, red, and magenta), as identified by sedimentological analysis. The modeled posterior distributions for the unit boundaries are shown in grey. (For interpretation of the references to color in this figure legend, the reader is referred to the web version of this article.)

deposition occurred between $44.3 \pm 3.4-22.5 \pm 6.0 \mathrm{ka}$ and $60.4 \pm 4.7-41.1 \pm 0.6 \mathrm{ka}$, respectively. Deposition of the overlying units (BL09, Unit B; BL18, Unit 2) initiated ca. $18.1 \pm 5.6 \mathrm{ka}$ and $31.2 \pm 6.5 \mathrm{ka}$, and ceased at $12.9 \pm 4.2 \mathrm{ka}$ and $15.5 \pm 3.0 \mathrm{ka}$, respectively.

\section{DISCUSSSION}

\section{North Stradbroke Island OSL dune ages}

The majority of dune crest ages in this study-excluding NSI18-7, for which the timing is uncertain due to the complex distribution of the grain populations (Fig. 5) - corroborate previously inferred dune activation during MIS 5 on North Stradbroke Island (Pickett et al., 1989; Tejan-Kella et al., 1990). Additionally, none of the final dune ages shown in Table 2 overlaps with the timing of the LGM (with the exception of the potentially compromised sample
NSI18-7), suggesting limited mobilization of dune material at this time, despite increased aridity inferred from low lake levels (Figs. 7, 8).

The mean OSL age for the samples in this study excluding NSI17-7 is $119.9 \pm 10.6 \mathrm{ka}$. Notably, this overlaps with the timing of the Yankee Jack unit emplacement reported (e.g., Ellerton et al., 2020) (Fig. 8) and supports the local distribution of the morphosequence as remapped using remote sensing (Patton et al., 2019) (Fig. 1b). The OSL results from this study show limited dune building during the LGM on North Stradbroke Island despite increased aridity, a similar finding to Fraser Island (da Silva and Shulmeister, 2016) and across the Cooloola Sand Mass (Ellerton et al., 2020). There appears to be a link between dune emplacement and higher sea-levels during MIS 5 (Fig. 8). This finding is in agreement with dune activation mechanisms proposed in the south-east Australian dune fields (Lees, 2006; Ellerton et al., 2020). Moreover, the absence of substantial evidence indicating Holocene 

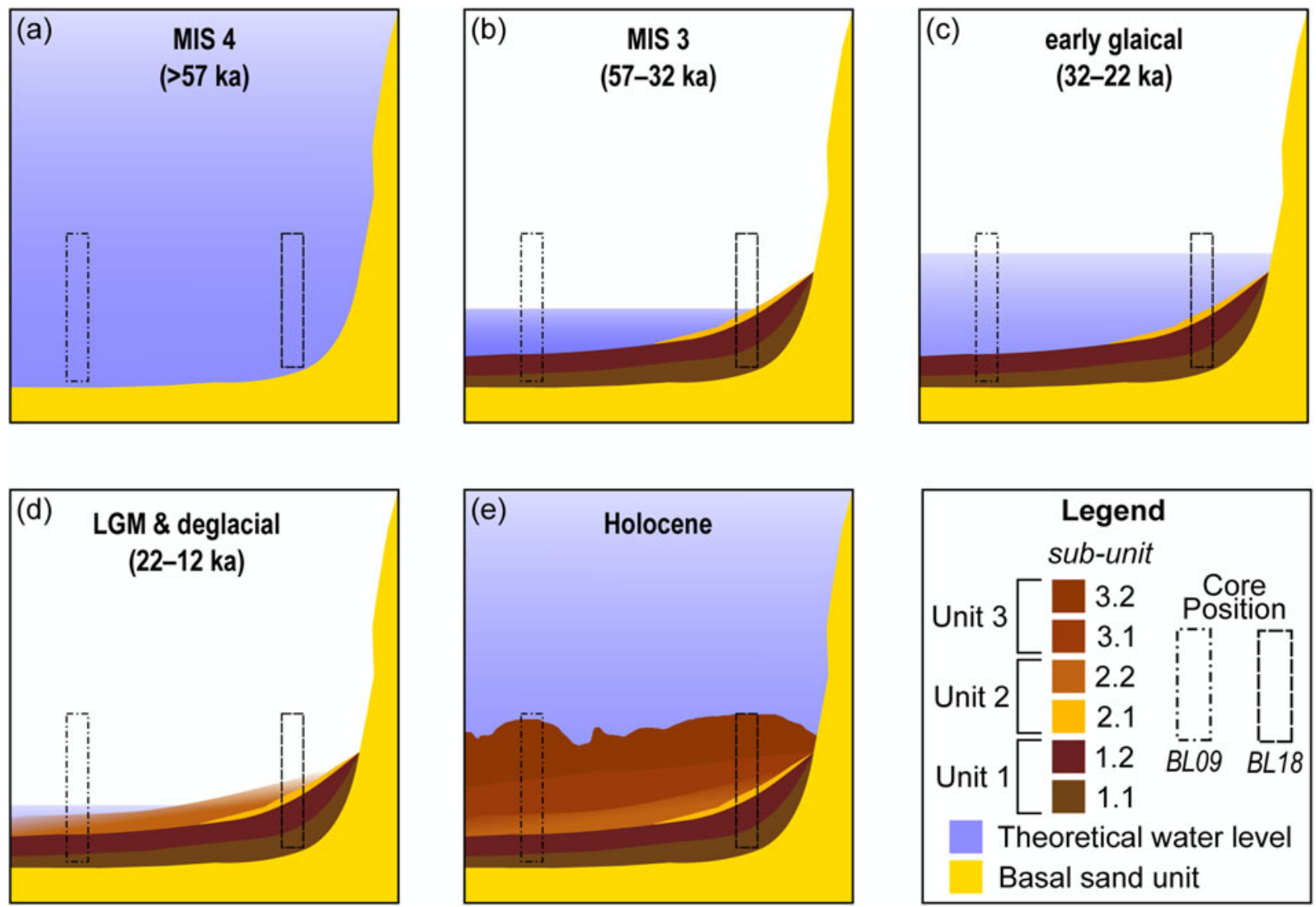

Figure 7. (color online) Conceptual model of sediment deposition and water level at Brown Lake during major climate phases referred to in text. The BL18 stratigraphic log was selected to represent the sedimentary units for the basin.

activation suggests the sand dunes had stabilized soon after deposition. However, an increase in the spatial resolution of dune samples across North Stradbroke Island is required to fully assess this hypothesis.

Lacustrine sediment accumulation in wetlands within the Yankee Jack dune sequence did not initiate synchronously, based on our regional dating comparison (i.e., Fern Gully Lagoon $=$ ca. $209 \mathrm{ka}$ [Kemp et al., 2020]; Welsby Lagoon $=$ ca. $83 \mathrm{ka}$ [Lewis et al., 2020]; and Brown Lake=ca. 60 ka) (Fig. 8). This supports the notion that the formation of the respective perching layers is not dictated purely by the mineralogical composition of the Yankee Jack dune sequence. Rather, it was likely a combination of local catchment morphology and hydroclimate (cf., Brooke et al., 2008).

\section{Brown Lake BL09 and BL18 age models}

The difference in sediment accumulation rate between the two Brown Lake records (Fig. 6) suggests that sedimentation was influenced by their position relative to water level (Fig. 7). The bathymetry of the modern lake-floor has a downwards slope trending in a north-east direction with an undulating surface (Fig. 2). During times of lower lake level, water turbulence in combination with the uneven surface may have changed the position of the fine-sediment accumulation zone (Blais and Kalff, 1995). This change in the sediment- focusing position would likely not affect the deposition of the sand band because this feature is likely accumulation of local material near the edge of the lake (Fig. 7); thus explaining why the distinctive sand band is observed in BL18 and not BL09.

The difference between the ages for the BL18 and BL09 records may also be grounded in the resolution of input parameters in the age model. The BL18 age-depth model has a resolution of more than three dating samples per meter (ten ${ }^{14} \mathrm{C}$ samples, including one replicate from 258 $\mathrm{cm}$, and one OSL sample), whereas BL09 has notably fewer (six ${ }^{14} \mathrm{C}$ samples and one OSL sample) (Tables 1,2). The proximity of the individual age estimates to the unit boundaries in each core also likely influences the age model outcomes. For example, the transition between Unit 2 and Unit 3 in BL18 is bracketed by ${ }^{14} \mathrm{C}$ samples OZX790 and OZX789 (Table 1; Fig. 2), thereby increasing confidence that the depositional interval has been modeled accurately. In contrast, the same boundary transition in the BL09 core (i.e., Unit B and Unit C transition) is not as well constrained, and the modeled age for Unit B relies on interpolation between ages from underlying and overlying units (Table 1, Fig. 6). The disparity in ages observed between parts of the BL18 and BL09 cores highlights the need to understand basin morphology, and the importance of developing robust age models before drawing inferences from paleoenvironmental proxies. 


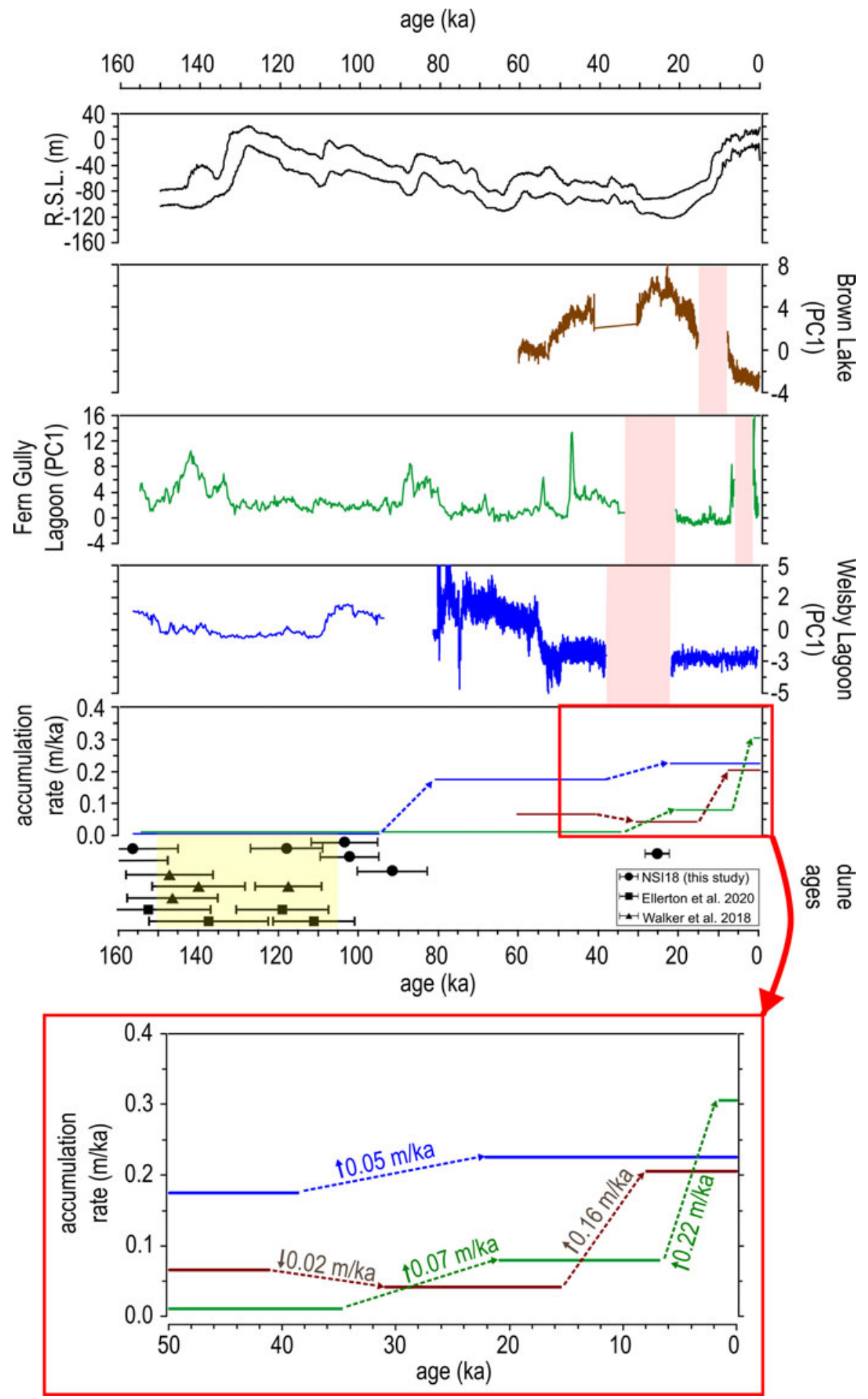

Figure 8. North Stradbroke Island wetland records with an extended range of inorganic sediment accumulation, and North Stradbroke Island dune crest ages over the last $160 \mathrm{ka}$. A global sea level curve is shown (Grant et al., 2014) (R.S.L.=relative sea level) along with the Brown Lake, Fern Gully Lagoon (Kemp et al., 2020), and Welsby Lagoon (Lewis et al., 2020) inorganic sediment accumulation records. The pink areas represent hiatus periods experienced at these wetlands. The red rectangle and arrow show the portion of the graph expanded in the bottom inset and identifies the change in mean accumulation rate between the wetland records. Dune OSL ages from this study (circles) are compared with those of Ellerton et al. (2020) (squares) and Walker et al. (2018) (triangles) from the Cooloola Sand Mass, with the timing of Yankee Jack dune building highlighted in yellow (Ellerton et al., 2020). (For interpretation of the references to color in this figure legend, the reader is referred to the web version of this article.) 


\section{History of aeolian sediment deposition in Brown Lake}

The change and variability inferred from Brown Lake are based on the BL18 record, which has the better age-depth model. Reconstructing the broader evolution of the wetland, however, considers both BL18 and BL09 (Fig. 7) and draws on comparisons to other North Stradbroke Island records where variation in inorganic sediment geochemistry has been used to infer aeolian deposition (e.g., Petherick et al., 2008; Moss et al., 2013; Kemp et al., 2020; Lewis et al., 2020). In this study, comparisons to Welsby Lagoon have utilized the alternate age-depth model presented in Lewis et al. (2020, fig. S5B). The use of this alternate age model was preferred given the co-occurrence of hydrological change inferred in the Brown Lake and Fern Gully Lagoon records, the expression of which appears dampened in Welsby Lagoon due to its transition from a lake to a swamp (Cadd et al., 2018). Use of this alternative age model is acceptable because it was shown to be relatively insensitive to the choice of stratigraphic priors (Lewis et al., 2020). Moreover, interpretations of dust flux were considered with respect to increased atmospheric dust loads (Harrison et al., 2001), which in Australia resulted from reduced vegetation due to drier climate (Hesse and McTainsh, 2003; McGowan et al., 2008), changing wind direction or strength (Kohfeld et al., 2013), sediment recharge in dust-source areas (Farebrother et al., 2017), or a complex mix of all these variables in response to hydrological variation (Marx et al., 2018).

\section{MIS $4(>57 \mathrm{ka})$}

The mean modeled age for the base of Brown Lake (BL18) is $60.4 \pm 4.7 \mathrm{ka}$ (Fig. 6), though the perched indurated layer must have formed before this time. Prior to this study, the oldest date from Brown Lake (BL09) was $47.2 \mathrm{ka}$ (Tibby et al., 2017). The early portion of the Brown Lake MIS 4 sedimentary record (Fig. 7a) likely accumulated during a phase of positive moisture balance with a lowered influx of aeolian material (Fig. 9) and lake-full conditions promoting substantial organic matter production and preservation (Fig. 7). The Fern Gully Lagoon record also has a low inorganic flux through MIS 4 (Kemp et al., 2020; Fig. 9), which may be related to increased vegetation cover. Because dust on North Stradbroke Island is sourced from the central Australian basins (Magee et al., 2004; Cohen et al., 2015; Miller et al., 2016) during MIS 4, it is likely that the coeval decline in dust flux is linked to wetter conditions regionally-an inference that would support the increase in rainforest taxa in ODP820 offshore from north-east Queensland (Kershaw et al., 2003). However, inferring climate from changes in dust flux sourced far afield should be made with caution because moisture and vegetation are not the only variables influencing dust mobilization. Dust flux can be influenced by source area surface aerodynamics (Webb and Strong, 2011) and sediment recharge (Marx et al., 2018). The inorganic flux to Brown Lake and North Stradbroke Island is likely influenced by widespread fluctuations in moisture across Australia (Farebrother et al., 2017), with an additional factor being changed vegetation regimes from deep-rooted trees and shrubs to grasses and herbs.

\section{MIS $3(57-32 \mathrm{ka})$}

The Brown Lake MIS 3 record shows increasing variation in $\mathrm{PC} 1$, attributed to progressively increasing influx of inorganic windswept material into the basin relative to MIS 4 (Fig. 9) rather than a proportional decrease in organic production (Fig. 7a, b). This is particularly notable between ca. 54 and 41 ka (Fig. 9), with concurrent trends observed in the Welsby Lagoon and the Fern Gully Lagoon records. However, unlike Fern Gully Lagoon, where two peaks of inorganic deposition occur at ca. $54 \mathrm{ka}$ and ca. $47 \mathrm{ka}$ (Kemp et al., 2020), the Brown Lake record shows a gradual increase in aeolian deposition through MIS 3, suggesting the difference may be attributed to local factors such as variation in lake water surface area, current flow, or vegetation regime changes influencing dust transport into the wetlands (Cadd et al., 2018). The history of marginal dune vegetation is not as well established for Brown Lake, in contrast to some other North Stradbroke Island sites (e.g., Moss et al., 2013).

\section{MIS 3 and early glacial period}

Through MIS 3, Brown Lake experienced a phase of sustained negative moisture balance, subsequently leading to shoreline transgression and deposition of the sandy sub-unit $2.1 \mathrm{ca} .30 .9 \mathrm{ka}$ (Fig. 7). The extent to which fire was a factor in enhancing local sand transportation remains unclear because charcoal records from nearby Welsby Lagoon show limited evidence for increased activity between MIS 4 and MIS 3 (Cadd et al., 2020). Moreover, owing to the lack of structure in the black muds (Unit 1) of Brown Lake, it is difficult to determine whether disruption occurred during the emplacement of the sandy sub-unit 2.1. Additionally, when considering the spatial variability factors such as fires and surface roughness have on sediment erosion (Sankey et al., 2011), it is unreasonable to exclude deposition of the sand layer as occurring as part of a rapid event (e.g., storm activity). Nevertheless, there is a relationship between the increase in dust flux to Brown Lake (Fig. 9) and lower lake water levels, indicating negative moisture balance locally.

Wetlands nearby Brown Lake, (i.e., Fern Gully Lagoon and Welsby Lagoon records) also show a hiatus in late MIS 3 (Figs. 8, 9) and support lower precipitation. This is contrary to the Tortoise Lagoon and Native Cosmpanion Lagoon records, which continue to accumulate dust through this phase, although at a decreased rate (McGowan et al., 2008; Petherick et al., 2008; Petherick et al., 2017), and generally support a regional shift towards warm and wet conditions; as suggested by pollen records (Moss et al., 2013). The disparity between these sites may be attributed to contrasting local catchment conditions and morphologies, which may have altered sediment infilling dynamics (e.g., Fern Gully Lagoon 

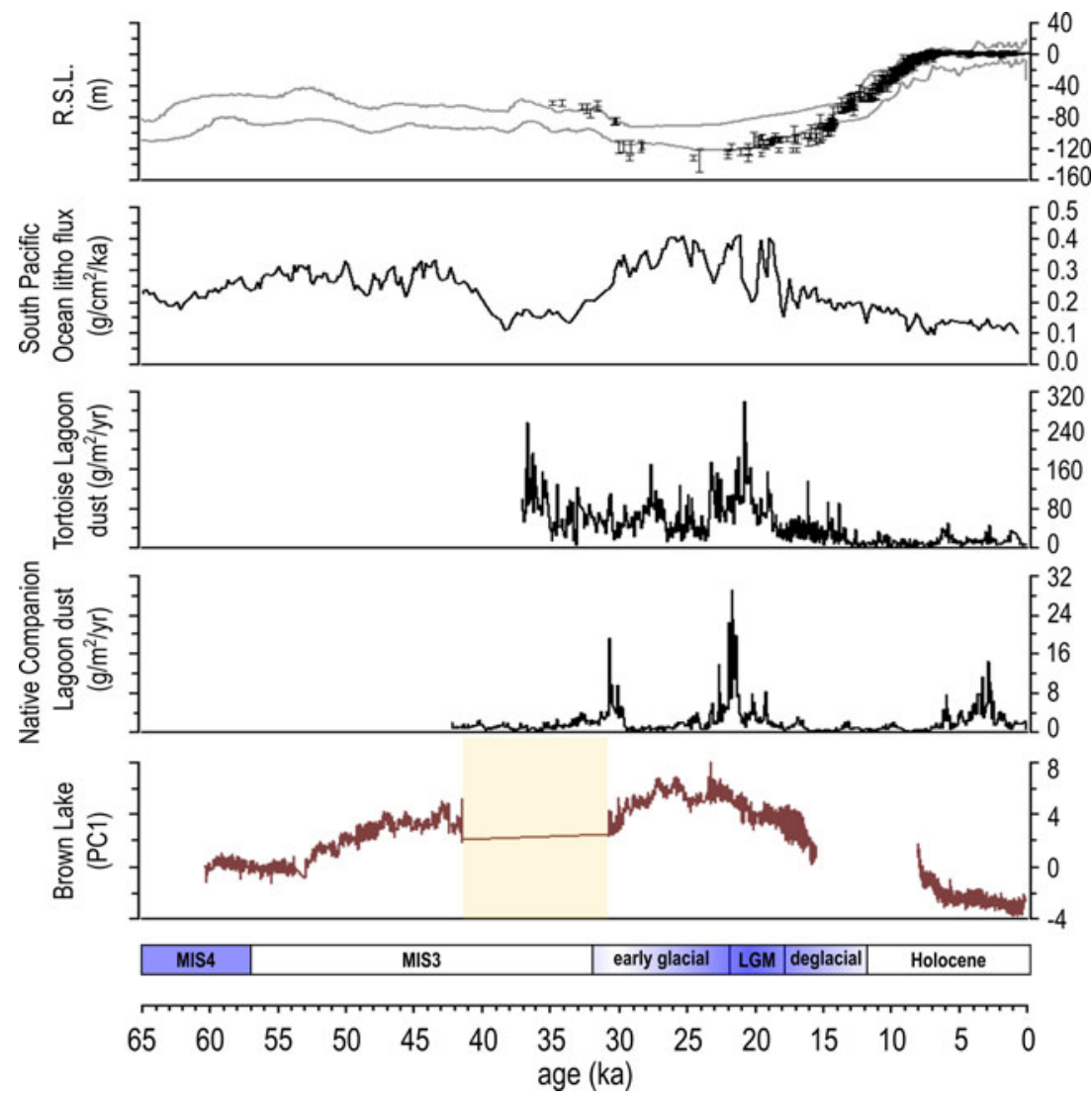

Figure 9. Compilation of dust and inorganic flux records from North Stradbroke Island and the ocean for the past 65 ka. Periods shown are modified from those identified in the OZ-INTIMATE climate synthesis (Reeves et al., 2013). The dust records shown include dust flux from Tortoise Lagoon, Native Companion Lagoon (Petherick et al., 2011, 2017), the South Pacific Ocean (Lamy et al., 2014), and Brown Lake. Relative sea level data from the Red Sea (Grant et al., 2014) are displayed in grey and overlain by composite sea-level record data (Lambeck et al., 2014). The yellow shaded box represents a potentially eroded section containing mixture of non-lacustrine and aeolian material, as discussed in the text. (For interpretation of the references to color in this figure legend, the reader is referred to the web version of this article.)

and Welsby Lagoon), shoreline migrations (e.g., Brown Lake), establishment of denser vegetation communities in close proximity (e.g., Tortoise Lagoon and Native Companion Lagoon), or a combination of these factors. Given age models show breaks in the Brown Lake, Fern Gully, and Welsby Lagoon cores are coeval, the cause of which is considered to be a result of more arid conditions attributed to changes in the relative positioning and strength of ENSO (Merkel et al., 2010) and key rainfall bands across the Pacific Ocean-as shown in modern interannual climate models (Brown et al., 2020). Therefore, the suppression of rainfall across the Brown Lake catchment during glacial times would cause water level to fall and shorelines to regress. Moreover, reduced evaporation from lowered temperatures may have prevented the lake drying completely as reported in nearby wetlands (Cadd et al., 2018). However, as presented in the age model results and supporting information, the choice of age model may affect the interpretation of lake evolution. As glacial conditions began to weaken North Atlantic meridional overturning circulation, thus modifying ENSO once more, changing local precipitation patterns and the strength of winds carrying continentally sourced dust to North Stradbroke Island (e.g., Harrison, 1993; Petherick et al., 2008). This ultimately drove the changes in lake water levels for wetlands, particularly Brown Lake, and allowed them to persist through MIS 2 (Figure 7c-d).

\section{Last glacial maximum $(22-18 \mathrm{ka})$}

The Brown Lake, Fern Gully Lagoon, and Welsby Lagoon sediment records show that there has been a pause in, or erosion of, lacustrine deposition leading into the LGM (Fig. 9). The difference between these records, despite their relatively close proximity $(<8 \mathrm{~km}$; Fig. 1), may reflect local variations in conditions favoring expansion of the indurating layer (Brooke et al., 2008), subsequently leaving wetlands with smaller perched aquifer catchments more susceptible to water level decline and shoreline regression during periods of moisture stress. Additionally, differences between the wetlands at this time (e.g., Welsby Lagoon transitioning into a swamp; Cadd et al., 2018) may have limited their ability to accumulate aeolian material. The various morphological changes that these wetlands can experience have profound influences on how records may be interpreted, highlighting 
the need establish thoroughly dated records in order reliably compare to regional archives of an early glacial change.

The Brown Lake record shows that dust deposition was highest through the early glacial and LGM phases, peaking at ca. $23 \mathrm{ka}$ (Fig. 9), a timing comparable to peaks observed in the Native Companion Lagoon (Petherick et al., 2008) and Tortoise Lagoon (Petherick et al., 2017). Considered together, the agreement between these North Stradbroke Island wetlands could indicate a localized signal attributed to dune destabilization from vegetation burning and enhanced dust mobilization, although there is limited change in the charcoal record (Cadd et al., 2020). A similar dust record is reflect in South Pacific Ocean marine cores (De Deckker, 2001; Lamy et al., 2014), where it is suggested dust generation was a result of regional climatic change. Thus, it can be inferred that the Brown Lake record hosts information related to the increased supply, entrainment, and transport of material from regional dust sources (Marx et al., 2018), the deflation of which was enhanced by drier conditions associated with the early glacial period and into the LGM. Moreover, the dust transportation pathways (Petherick et al., 2009) show the source of the inorganic material was far-travelled, originating from the Australian mainland, where dust generation was linked to changes in moisture balance (Hesse and McTainsh, 2003). Movement of the South Pacific Convergence Zone and the on-flowing effect to how ENSO is expressed have the capacity to influence generally drier conditions, including enhancement of the SW winds, through displacement and suppression of other synoptic fronts on the east coast (Rudeva et al., 2019; Brown et al., 2020).

The modeled mean accumulation rate for Brown Lake through the LGM $(0.04 \mathrm{~m} / \mathrm{ka})$ was surprisingly lower than MIS $3(0.06 \mathrm{~m} / \mathrm{ka}$ ) (Fig. 8), although this may reflect limited age-model precision between Unit 2 and Unit 1. Therefore, the Brown Lake data should be expected to be in agreement with Fern Gully Lagoon and Welsby Lagoon, which show accumulation rates increasing from $0.01 \mathrm{~m} / \mathrm{ka}$ to $0.08 \mathrm{~m} / \mathrm{ka}$ (Kemp et al., 2020) and $0.17 \mathrm{~m} / \mathrm{ka}$ to $0.23 \mathrm{~m} / \mathrm{ka}$ (Lewis et al., 2020), respectively (Fig. 8). Furthermore, an increase in lithogenic material accumulation would correlate with increased atmospheric dust loads (Harrison et al., 2001), which likely resulted from drier climate, albeit modulated by other factors.

The variation in chemical composition in the Brown Lake record for the early glacial phase and LGM (i.e., the clays of Unit 2) supports the hypothesis that dust was being sourced outside of North Stradbroke Island (Petherick et al., 2009). Moreover, the sedimentological properties of sub-unit 2.2 suggest that the Brown Lake water level fluctuated soon after the LGM, falling below the sediment surface between $15.4 \pm 3.1 \mathrm{ka}$ (top of Unit 2) and $8.0 \pm 0.2 \mathrm{ka}$ (bottom of Unit 3) (Fig. 7c, d). The timing of this break in sedimentation is different from other North Stradbroke Island wetlands (Fig. 9) and may be a product of different conditions between each catchment, or their respective age models. Nevertheless, the mechanism influencing precipitation across the catchments is likely regional, possibly linked to the Antarctic Cold Reversal (Barr et al., 2017), or ENSO because geographically separate climate records across the Australian continent also indicate a change towards more positive moisture balance during the deglacial phase (Turney et al., 2006b; Williams et al., 2009; Petherick et al., 2013).

\section{The Holocene (11.7-0 ka)}

Following the depositional hiatus at Brown Lake during the deglacial period, a return to higher lake levels, according to our model, occurred ca. $8 \mathrm{ka}$ and allowed aeolian inorganic material to accumulate once again. Notably, the timing of the hiatus is in agreement with drier conditions observed in Lake Allom from the nearby Fraser Island (Donders et al., 2006). Because the increase in lake water level is coeval between two separate lakes, it is more likely this reflects a regional increase in moisture across eastern Australia, the timing of which aligns with enhancement of Southern Hemisphere circulation (Woodward et al., 2014). The Brown Lake, Welsby Lagoon, and Fern Gully Lagoon records have contrasting Holocene dust flux, with Brown Lake showing a declining PC1 signal, Welsby Lagoon relatively stable (Lewis et al., 2020), and Fern Gully Lagoon showing an increasing flux (Kemp et al., 2020) (Fig. 9). The variance between the records may be linked to differing hydrological sensitivities, chronological model frameworks, or other site-specific factors (Cadd et al., 2018) Conversely, following the hiatus at Brown Lake, the basin returned to a deeper lacustrine system similar to its expression today (Fig. 7e). Elsewhere, the smaller catchment size of Fern Gully Lagoon relative to other North Stradbroke Island wetlands (Kemp et al., 2020) appears to have increased the wetland's susceptibility to drying out during periods of lower rainfall on the island (Barr et al., 2019).

Differing human land-use practices may also be a factor in the different signals observed in the wetland records. Increased burning may have induced changes in vegetation cover (Barr et al., 2017; Mariani et al., 2019), thereby altering the erosivity of the soil. However, information pertaining to human occupation on North Stradbroke Island is limited, with late Pleistocene archaeological evidence from Wallen Wallen Creek providing the earliest known activity (ca. $20,560 \pm 250{ }^{14} \mathrm{C}$ yr BP [SUA-2341]; Neal and Stock, 1986).

\section{CONCLUSION}

Single-grain OSL ages obtained on dune crests in this study indicate activation of the Yankee Jack dune sequence on North Stradbroke Island through MIS 5, the earliest initiation being $167.8 \pm 19.1 \mathrm{ka}$. Subsequent to this prominent phase of dune building, there was long-term stabilization of the local dune landscape with no indication of subsequent large-scale dune mobilization. This may be attributed to vegetation stabilizing the MIS 5 age dunes of North Stradbroke Island shortly after emplacement by $91.0 \pm 9.1 \mathrm{ka}$. 
The new paleoenvironmental record from Brown Lake, which includes a Bayesian age depth model derived from $10{ }^{14} \mathrm{C}$ ages and an OSL date, has enabled inference of climate variability over the past $60 \mathrm{ka}$. Geochemical and sedimentological changes, driven by changes in dust deposition, highlight the sensitivity of this perched wetland to climate change. The age model suggests the sedimentary sequence is continuous from lake initiation to the LGM. However, the sedimentology at the base of Unit 2 may indicate dry lake conditions or rapid sand deposition; further chronological control through this part of the record is required to differentiate between these scenarios. Nevertheless, from late MIS 3 and MIS 2 the dust flux signal intensifies across North Stradbroke Island, the result of which aligns with continental aridification and ecological change across Australia.

The increase in dust deposition across Brown Lake, Tortoise Lagoon, and Native Companion Lagoon during the early glacial phase and LGM, and the coeval hiatuses between Brown Lake and nearby wetlands, support a climatedriven local expression of negative moisture balance. This contrasts with interferences of a largely positive moisture balance at this time (e.g., Moss et al., 2013; Tibby et al., 2017), however it should be noted these have relatively fewer dates incorporated into the respective age models. Hence there is a need for better chronological controls so that local and regional changes can be evaluated. The inferred negative hydrological period in this study is in agreement with other terrestrial records across mainland Australia and New Zealand, potentially linked to changes in the positioning of the South Pacific Convergence Zone (Brown et al., 2020), ENSO (Merkel et al., 2010), South Westerly Winds (Rudeva et al., 2019), or a combination thereof. Comparisons of Brown Lake to proximal wetlands through MIS 2 in particular (i.e., Welsby Lagoon and Fern Gully Lagoon) have highlighted the importance of understanding variations in local catchment ecology and morphology, particularly when considering the impact of basin infilling on paleoenvironmental records.

The return to a more positive moisture balance at Brown Lake in the early Holocene, and the recommencement of sediment accumulation, suggests a local shift from dry to wet. However, interrogating the dust record alone for regional changes in climate following recommencement is less reliable because landscape alteration from human practices both locally and in source locations had likely initiated. In order to better understand the effects of climate variation on the environment, particularly in association with the LGM and climate extremes, multi-proxy analytical approaches should also consider the surrounding landscape (e.g., associated dune deposits), which may hold missing or complementary information about local variations in environmental conditions.

\section{ACKNOWLEDGMENTS}

We acknowledge Minjerribah (North Stradbroke Island) and the surrounding waters as Quandamooka Country and thank the
Quandamooka Yoolooburrabee Aboriginal Corporation for permission to undertake the work. We thank Haidee Cadd and Jo Blessing for assistance in the field and Chris Kemp for discussions pertaining to Fern Gully Lagoon. Many thanks are also extended to Jonathan Marshall and Glenn McGregor for assistance in data acquisition. The work was supported by the Australian Research Council Discovery Project (DP150103875). R.L. was supported by an Australian Government Research Training Program Scholarship and a CRC LEME Regolith Science Scholarship. The OSL dating was supported by Australian Research Council Future Fellowship (FT130100195). Radiocarbon dating and XRF core scanning was made possible through the ANSTO facility access program (AP11643; AP12402). We acknowledge the financial support from the Australian Government for the Centre for Accelerator Science at ANSTO through the National Collaborative Research Infrastructure Strategy (NCRIS).

\section{SUPPLEMENTARY MATERIAL}

The supplementary material for this article can be found at https:// doi.org/10.1017/qua.2020.117

\section{REFERENCES}

Aitken, M.J., 1998. An Introduction to Optical Dating: The Dating of Quaternary Sediments by the Use of Photon-Stimulated Luminescence. Oxford University Press, Oxford.

Arnold, L.J., Bailey, R.M., Tucker, G.E., 2007. Statistical treatment of fluvial dose distributions from southern Colorado arroyo deposits. Quaternary Geochronology 2, 162-167.

Arnold, L.J., Duval, M., Falguères, C., Bahain, J.J., Demuro, M., 2012. Portable gamma spectrometry with cerium-doped lanthanum bromide scintillators: suitability assessments for luminescence and electron spin resonance dating applications. Radiation Measurements 47, 6-18.

Arnold, L.J., Roberts, R.G., 2011. Paper I-Optically stimulated luminescence (OSL) dating of perennially frozen deposits in north-central Siberia: OSL characteristics of quartz grains and methodological considerations regarding their suitability for dating. Boreas 40, 389-416.

Arnold, L., Roberts, R., 2009. Stochastic modelling of multi-grain equivalent dose (De) distributions: Implications for OSL dating of sediment mixtures. Quaternary Geochronology 4, 204-230.

Barr, C., Tibby, J., Leng, M.J., Tyler, J.J., Henderson, A.C.G., Overpeck, J.T., Simpson, G.L., et al., 2019. Holocene El Niño-Southern Oscillation variability reflected in subtropical Australian precipitation. Scientific Reports 9, 1627. https://doi.org/10.1038/ s41598-019-38626-3.

Barr, C., Tibby, J., Moss, P.T., Halverson, G.P., Marshall, J.C., McGregor, G.B., Stirling, E., 2017. A 25,000-year record of environmental change from Welsby Lagoon, North Stradbroke Island, in the Australian subtropics. Quaternary International $449,106-118$.

Barrows, T.T., Juggins, S., 2005. Sea-surface temperatures around the Australian margin and Indian Ocean during the Last Glacial Maximum. Quaternary Science Reviews 24, 1017-1047.

Birks, H.H., Birks, H.J.B., 2006. Multi-proxy studies in palaeolimnology. Vegetation History and Archaeobotany 15, 235-251.

Blais, J.M., Kalff, J., 1995. The influence of lake morphometry on sediment focusing. Limnology and Oceanography 40, 582-588. 
BOM, 2019. Climate Data Online. Australian Government, Bureau of Meteorology. http://www.bom.gov.au/climate/data/.

Bøtter-Jensen, L., Mejdahl, V., 1988. Assessment of beta dose-rate using a GM multicounter system. International Journal of Radiation Applications and Instrumentation. Part D. Nuclear Tracks and Radiation Measurements 14, 187-191.

Bowler, J.M., 1976. Aridity in Australia: age, origins and expression in aeolian landforms and sediments. Earth-Science Reviews 12, 279-310.

Boyle, J., 2002. Inorganic geochemical methods in palaeolimnology. In: Last, W.M., Smol, J.P. (Eds.), Tracking Environmental Change Using Lake Sediments. Springer Netherlands, pp. 83-141.

Brennan, B.J., 2003. Beta doses to spherical grains. Radiation Measurements 37, 299-303.

Brock, F., Higham, T., Ditchfield, P., Ramsey, C.B., 2010. Current pretreatment methods for AMS radiocarbon dating at the Oxford Radiocarbon Accelerator Unit (ORAU). Radiocarbon 52, 103-112.

Bronk Ramsey, C., 2009. Dealing with outliers and offsets in radiocarbon dating. Radiocarbon 51, 1023-1045.

Bronk Ramsey, C., 2017. Methods for summarizing radiocarbon datasets. Radiocarbon 59, 1809-1833.

Bronk Ramsey, C., Lee, S., 2013. Recent and planned developments of the program OxCal. Radiocarbon 55, 720-730.

Brooke, B., Preda, M., Lee, R., Cox, M., Olley, J., Pietsch, T., Price, D., 2008. Development, composition and age of indurated sand layers in the Late Quaternary coastal deposits of northern Moreton Bay, Queensland. Australian Journal of Earth Sciences 55, 141-157.

Brown, J.R., Lengaigne, M., Lintner, B.R., Widlansky, M.J., Van Der Wiel, K., Dutheil, C., Linsley, B.K., Matthews, A.J., Renwick, J., 2020. South Pacific Convergence Zone dynamics, variability and impacts in a changing climate. Nature Reviews Earth \& Environment 1, 530-543. https://doi.org/10.1038/ s43017-020-0078-2

Cadd, H.R., Tibby, J., Barr, C., Tyler, J., Unger, L., Leng, M.J., Marshall, J.C., McGregor, G., Lewis, R., Arnold, L.J., 2018. Development of a southern hemisphere subtropical wetland (Welsby Lagoon, south-east Queensland, Australia) through the last glacial cycle. Quaternary Science Reviews 202, 53-65.

Cadd, H.R., Tyler, J., Tibby, J., Baldock, J., Hawke, B., Barr, C., Leng, M.J., 2020. The potential for rapid determination of charcoal from wetland sediments using infrared spectroscopy. Palaeogeography, Palaeoclimatology, Palaeoecology 542, 109562. http://dx.doi.org/10.1016/j.palaeo.2019.109562.

Clark, P.U., Dyke, A.S., Shakun, J.D., Carlson, A.E., Clark, J., Wohlfarth, B., Mitrovica, J.X., Hostetler, S.W., McCabe, A.M., 2009. The last glacial maximum. Science 325, 710-714.

Clifford, H.T., Specht, R.L., 1979. The Vegetation of North Sradbroke Island. University of Queensland, St. Lucia, Australia.

Cohen, T.J., Jansen, J.D., Gliganic, L.A., Larsen, J.R., Nanson, G.C., May, J.H., Jones, B.G., Price, D.M., 2015. Hydrological transformation coincided with megafaunal extinction in central Australia. Geology 43, 195-198.

Colhoun, E.A., Pola, J.S., Barton, C.E., Heijnis, H., 1999. Late Pleistocene vegetation and climate history of Lake Selina, western Tasmania. Quaternary International 57, 5-23.

Colls, K., Whitaker, R., 1990. The Australian Weather Book. Associates Publishing Pty Ltd, Sydney, Australia.

Croudance, I.W., Rothwell, G.R., 2015. Micro-XRF Studies of Sediment Cores. Springer, Dordrecht, Heidelberg, New York, London. da Silva, M.G., Shulmeister, J., 2016. A review of coastal dunefield evolution in southeastern Queensland. Journal of Coastal Research 75, 308-312.

Davies, S.J., Lamb, H.F., Roberts, S.J., 2015. Micro-XRF core scanning in palaeolimnology: recent developments. In: Croudace, I.W., Rothwell, R.G. (Eds.), Micro-XRF Studies of Sediment Cores: Applications of a Non-Destructive Tool for the Environmental Sciences. Developments in Paleoenvironmental Research 17, Springer, pp. 189-226.

De Deckker, P., 2001. Late Quaternary cyclic aridity in tropical Australia. Palaeogeography, Palaeoclimatology, Palaeoecology 170, 1-9.

Demuro, M., Arnold, L.J., Froese, D.G., Roberts, R.G., 2013. OSL dating of loess deposits bracketing Sheep Creek tephra beds, Northwest Canada: dim and problematic single-grain OSL characteristics and their effect on multi-grain age estimates. Quaternary Geochronology 15, 67-87.

Denton, G.H., Heusser, C., Lowel, T., Moreno, P.I., Andersen, B.G., Heusser, L.E., Schlühter, C., Marchant, D.R., 1999. Interhemispheric linkage of paleoclimate during the last glaciation. Geografiska Annaler: Series A, Physical Geography 81, 107-153.

Donders, T.H., Wagner, F., Visscher, H., 2006. Late Pleistocene and Holocene subtropical vegetation dynamics recorded in perched lake deposits on Fraser Island, Queensland, Australia. Palaeogeography, Palaeoclimatology, Palaeoecology 241, 417-439.

Ellerton, D., Rittenour, T., Shulmeister, J., Gontz, A., Welsh, K.J., Patton, N., 2020. An 800 kyr record of dune emplacement in relationship to high sea level forcing, Cooloola Sand Mass, Queensland, Australia. Geomorphology 354, 106999. https://doi.org/10. 1016/j.geomorph.2019.106999.

Ellerton, D., Shulmeister, J., Woodward, C., Moss, P., 2017. Last Glacial Maximum and Last Glacial-Interglacial Transition pollen record from northern NSW, Australia: evidence for a humid late Last Glacial Maximum and dry deglaciation in parts of eastern Australia. Journal of Quaternary Science 32, 717-728.

Farebrother, W., Hesse, P.P., Chang, H.-C., Jones, C., 2017. Dry lake beds as sources of dust in Australia during the Late Quaternary: a volumetric approach based on lake bed and deflated dune volumes. Quaternary Science Reviews 161, 81-98.

Fitzsimmons, K.E., Bowler, J.M., Rhodes, E.J., Magee, J.M., 2007. Relationships between desert dunes during the late Quaternary in the Lake Frome region, Strzelecki Desert, Australia. Journal of Quaternary Science 22, 549-558.

Galbraith, R.F., Roberts, R.G., Laslett, G.M., Yoshida, H., Olley, J.M., 1999. Optical dating of single and multiple grains of quartz from Jinmium Rock Shelter, Northern Australia: part I, experimental design and statistical models. Archaeometry 41, 339-364.

Galbraith, R., Green, P., 1990. Estimating the component ages in a finite mixture. International Journal of Radiation Applications and Instrumentation. Part D. Nuclear Tracks and Radiation Measurements 17, 197-206.

Galloway, R., 1965. Late Quaternary climates in Australia. The Journal of Geology 73, 603-618.

Gasse, F., Van Campo, E., 2001. Late Quaternary environmental changes from a pollen and diatom record in the southern tropics (Lake Tritrivakely, Madagascar). Palaeogeography, Palaeoclimatology, Palaeoecology 167, 287-308.

Gordon, A.D., 1982. An investigation of two sequence comparison statistics. Australian Journal of Statistics 3, 332-342.

Grant, K., Rohling, E., Ramsey, C.B., Cheng, H., Edwards, R., Florindo, F., Heslop, D., Marra, F., Roberts, A., Tamisiea, 
M.E., 2014. Sea-level variability over five glacial cycles. Nature Communications 5, 5076. https://doi.org/10.1038/ncomms6076.

Guérin, G., Mercier, N., Adamiec, G., 2011. Dose-rate conversion factors: update. Ancient TL 29, 5-8.

Guyard, H., Chapron, E., St-Onge, G., Anselmetti, F.S., Arnaud, F., Magand, O., Francus, P., Mélières, M.-A., 2007. High-altitude varve records of abrupt environmental changes and mining activity over the last 4000 years in the Western French Alps (Lake Bramant, Grandes Rousses Massif). Quaternary Science Reviews 26, 2644-2660

Harrison, S.P., 1993. Late Quaternary lake-level changes and climates of Australia. Quaternary Science Reviews 12, 211-231.

Harrison, S.P., Kohfeld, K.E., Roelandt, C., Claquin, T., 2001. The role of dust in climate changes today, at the last glacial maximum and in the future. Earth-Science Reviews 54, 43-80.

Heiri, O., Lotter, A.F., Lemcke, G., 2001. Loss on ignition as a method for estimating organic and carbonate content in sediments: reproducibility and comparability of results. Journal of Paleolimnology 25, 101-110.

Hendy, I.L., Napier, T.J., Schimmelmann, A., 2015. From extreme rainfall to drought: 250 years of annually resolved sediment deposition in Santa Barbara Basin, California. Quaternary International 387, 3-12.

Hesse, P.P., 2016. How do longitudinal dunes respond to climate forcing? Insights from 25 years of luminescence dating of the Australian desert dunefields. Quaternary International 410, 11-29.

Hesse, P.P., Magee, J.W., Van Der Kaars, S., 2004. Late Quaternary climates of the Australian arid zone: a review. Quaternary International 118, 87-102.

Hesse, P.P., McTainsh, G.H., 2003. Australian dust deposits: modern processes and the Quaternary record. Quaternary Science Reviews 22, 2007-2035.

Hogg, A.G., Hua, Q., Blackwell, P.G., Niu, M., Buck, C.E., Guilderson, T.P., Heaton, T.J., Palmer, J.G., Reimer, P.J., Reimer, R.W., 2013. SHCal13 Southern Hemisphere calibration, 0-50,000 years cal BP. Radiocarbon 55, 1889-1903.

Hounslow, M.W., Clark, R.M., 2016. CPLSlot a program for objective correlation between successions using sequence slotting. https://doi.org/10.13140/RG.2.2.17513.29288.

Jouve, G., Francus, P., Lamoureux, S., Provencher-Nolet, L., Hahn, A., Haberzettl, T., Fortin, D., Nuttin, L., Team, T.P.S., 2013. Microsedimentological characterization using image analysis and $\mu-\mathrm{XRF}$ as indicators of sedimentary processes and climate changes during Lateglacial at Laguna Potrok Aike, Santa Cruz, Argentina. Quaternary Science Reviews 71, 191-204.

Kemp, C.W., Tibby, J., Arnold, L.J., Barr, C., Gadd, P.S., Marshall, J.C., McGregor, G.B., Jacobsen, G.E., 2020. Climates of the last three interglacials in subtropical eastern Australia inferred from wetland sediment geochemistry. Palaeogeography, Palaeoclimatology, Palaeoecology 538, 109463. https://doi.org/10.1016/j. palaeo.2019.109463.

Kemp, J., Spooner, N.A., 2007. Evidence for regionally wet conditions before the LGM in southeast Australia: OSL ages from a large palaeochannel in the Lachlan Valley. Journal of Quaternary Science 22, 423-427.

Kershaw, A.P., McKenzie, G.M., Brown, J., Roberts, R.G., van der Kaars, W., 2010. Beneath the Peat: A Refined Pollen Record from an Interstadial at Caledonia Fen, Highland Eastern Victoria, Australia. ANU E Press, Canberra, Australia.

Kershaw, A.P., McKenzie, G.M., Porch, N., Roberts, R.G., Brown, J., Heijnis, H., Orr, M.L., Jacobsen, G., Newall, P.R., $2007 \mathrm{~b}$.
A high-resolution record of vegetation and climate through the last glacial cycle from Caledonia Fen, southeastern highlands of Australia. Journal of Quaternary Science 22, 481-500.

Kershaw, A., Van Der Kaars, S., Moss, P., 2003. Late Quaternary Milankovitch-scale climatic change and variability and its impact on monsoonal Australasia. Marine Geology 201, 81-95.

Kershaw, P., van der Kaars, S., Moss, P., Opdyke, B., Guichard, F., Rule, S., Turney, C., 2006. Environmental change and the arrival of people in the Australian region. Before Farming 2006, 1-24.

Kohfeld, K.E., Graham, R.M., de Boer, A.M., Sime, L.C., Wolff, E.W., Le Quéré, C., Bopp, L., 2013. Southern Hemisphere westerly wind changes during the Last Glacial Maximum: paleo-data synthesis. Quaternary Science Reviews 68, 76-95.

Kylander, M.E., Ampel, L., Wohlfarth, B., Veres, D., 2011. Highresolution X-ray fluorescence core scanning analysis of Les Echets (France) sedimentary sequence: new insights from chemical proxies. Journal of Quaternary Science 26, 109-117.

Kylander, M.E., Lind, E.M., Wastegård, S., Löwemark, L., 2012. Recommendations for using XRF core scanning as a tool in tephrochronology. The Holocene 22, 371-375.

Lambeck, K., Rouby, H., Purcell, A., Sun, Y., Sambridge, M., 2014. Sea level and global ice volumes from the Last Glacial Maximum to the Holocene. Proceedings of the National Academy of Sciences 111, 15296-15303.

Lamy, F., Gersonde, R., Winckler, G., Esper, O., Jaeschke, A., Kuhn, G., Ullermann, J., Martinez-Garcia, A., Lambert, F., Kilian, R., 2014. Increased dust deposition in the Pacific Southern Ocean during glacial periods. Science 343, 403-407.

Lauterbach, S., Brauer, A., Andersen, N., Danielopol, D.L., Dulski, P., Hüls, M., Milecka, K., Namiotko, T., Obremska, M., Von Grafenstein, U., 2011. Environmental responses to Lateglacial climatic fluctuations recorded in the sediments of pre-Alpine Lake Mondsee (northeastern Alps). Journal of Quaternary Science 26, 253-267.

Leach, L.M., 2011. Hydrology and physical setting of North Stradbroke Island. Proceedings of the Royal Society of Queensland $117,21-46$.

Lees, B., 2006. Timing and formation of coastal dunes in northern and eastern Australia. Journal of Coastal Research 2006, 78-89.

Lewis, R.J., Tibby, J., Arnold, L.J., Barr, C., Marshall, J., McGregor, G., Gadd, P., Yokoyama, Y., 2020. Insights into subtropical Australian aridity from Welsby Lagoon, north Stradbroke Island, over the past 80,000 years. Quaternary Science Reviews 234, 106262. https://doi.org/10.1016/j.quascirev.2020.106262.

Lisé-Pronovost, A., Fletcher, M.-S., Mallett, T., Mariani, M., Lewis, R., Gadd, P., Herries, A., Blaauw, M., Heijnis, H., Hodgson, D., 2019. Scientific Drilling of Lake Sediments at Darwin Crater, Tasmania. Scientific Drilling 25, 1-14.

Long, K., Wood, R., Williams, I.S., Kalish, J., Shawcross, W., Stern, N., Grün, R., 2018. Fish otolith microchemistry: snapshots of lake conditions during early human occupation of Lake Mungo, Australia. Quaternary International 463, 29-43.

Magee, J.W., Miller, G.H., Spooner, N.A., Questiaux, D., 2004. Continuous 150 ky monsoon record from Lake Eyre, Australia: insolation-forcing implications and unexpected Holocene failure. Geology 32, 885-888.

Mandl, M.B., Shuman, B.N., Marsicek, J., Grigg, L., 2016. Estimating the regional climate signal in a late Pleistocene and early Holocene lake-sediment $\delta^{18} \mathrm{O}$ record from Vermont, USA. Quaternary Research 86, 67-78.

Mariani, M., Tibby, J., Barr, C., Moss, P., Marshall, J.C., McGregor, G.B., 2019. Reduced rainfall drives biomass limitation of long- 
term fire activity in Australia's subtropical sclerophyll forests. Journal of Biogeography 46, 1974-1987.

Marx, S.K., Kamber, B.S., McGowan, H.A., Petherick, L.M., McTainsh, G.H., Stromsoe, N., Hooper, J.N., May, J.-H., 2018. Palaeo-dust records: a window to understanding past environments. Global and Planetary Change 165, 13-43.

McCanta, M.C., Hatfield, R.G., Thomson, B.J., Hook, S.J., Fisher, E., 2015. Identifying cryptotephra units using correlated rapid, nondestructive methods: VSWIR spectroscopy, X-ray fluorescence, and magnetic susceptibility. Geochemistry, Geophysics, Geosystems 16, 4029-4056.

McGowan, H.A., Petherick, L.M., Kamber, B.S., 2008. Aeolian sedimentation and climate variability during the late Quaternary in southeast Queensland, Australia. Palaeogeography, Palaeoclimatology, Palaeoecology 265, 171-181.

Mejdahl, V., 1979. Thermoluminescence dating: Beta-dose attenuation in quartz grains. Archaeometry 21, 61-72.

Merkel, U., Prange, M., Schulz, M., 2010. ENSO variability and teleconnections during glacial climates. Quaternary Science Reviews 29, 86-100.

Miller, G.H., Fogel, M.L., Magee, J.W., Gagan, M.K., 2016. Disentangling the impacts of climate and human colonization on the flora and fauna of the Australian arid zone over the past $100 \mathrm{ka}$ using stable isotopes in avian eggshell. Quaternary Science Reviews 151, 27-57.

Mosisch, T.D., Arthington, A.H., 2001. Polycyclic aromatic hydrocarbon residues in the sediments of a dune lake as a result of power boating. Lakes \& Reservoirs: Research and Management 6, 21-32.

Moss, E., 2013. A Dust Record from Lacustrine Sediments on North Stradbroke Island, Queensland: Evidence for Climate Variability in Central and Southeastern Australia During the Late Quaternary [Bachelor's thesis]. The University of Sydney, Sydney, Australia, $152 \mathrm{p}$.

Moss, P.T., Kershaw, A.P., 2007. A late Quaternary marine palynological record (oxygen isotope stages 1 to 7 ) for the humid tropics of northeastern Australia based on ODP Site 820. Palaeogeography, Palaeoclimatology, Palaeoecology 251, 4-22.

Moss, P.T., Tibby, J., Petherick, L., McGowan, H., Barr, C., 2013. Late Quaternary vegetation history of North Stradbroke Island, Queensland, eastern Australia. Quaternary Science Reviews 74, 257-272.

Murray, A.S., Wintle, A.G., 2000. Luminescence dating of quartz using an improved single-aliquot regenerative-dose protocol. Radiation Measurements 32, 57-73.

Nathan, R.P., Thomas, P.J., Jain, M., Murray, A.S., Rhodes, E.J., 2003. Environmental dose rate heterogeneity of beta radiation and its implications for luminescence dating: Monte Carlo modelling and experimental validation. Radiation Measurements 37, 305-313.

Neal, R., Stock, E., 1986. Pleistocene occupation in the south-east Queensland coastal region. Nature 323, 618-621.

Niemann, H., Matthias, I., Michalzik, B., Behling, H., 2013. Late Holocene human impact and environmental change inferred from a multi-proxy lake sediment record in the Loja region, southeastern Ecuador. Quaternary International 308-309, 253-264.

Olley, J.M., Pietsch, T., Roberts, R.G., 2004. Optical dating of Holocene sediments from a variety of geomorphic settings using single grains of quartz. Geomorphology 60, 337-358.

Patton, N.R., Ellerton, D., Shulmeister, J., 2019. High-resolution remapping of the coastal dune fields of south east Queensland,
Australia: a morphometric approach. Journal of Maps 15, 578589.

Petherick, L., Bostock, H., Cohen, T.J., Fitzsimmons, K., Tibby, J., Fletcher, M.-S., Moss, P., Reeves, J., Mooney, S., Barrows, T., 2013. Climatic records over the past $30 \mathrm{ka}$ from temperate Australia-a synthesis from the Oz-INTIMATE workgroup. Quaternary Science Reviews 74, 58-77.

Petherick, L., McGowan, H. and Moss, P., 2008. Climate variability during the Last Glacial Maximum in eastern Australia: evidence of two stadials? Journal of Quaternary Science 23, 787-802.

Petherick, L.M., McGowan, H.A., Kamber, B.S., 2009. Reconstructing transport pathways for late Quaternary dust from eastern Australia using the composition of trace elements of long traveled dusts. Geomorphology 105, 67-79.

Petherick, L.M., Moss, P.T., McGowan, H.A., 2011. Climatic and environmental variability during the termination of the Last Glacial Stage in coastal eastern Australia: a review. Australian Journal of Earth Sciences 58, 563-577.

Petherick, L., Moss, P., McGowan, H., 2017. An extended Last Glacial Maximum in subtropical Australia. Quaternary International 432, 1-12.

Pickett, J.W., Ku, T.L., Thompson, C.H., Roman, D., Kelley, R.A., Huang, Y.P., 1989. A review of age determinations on Pleistocene corals in eastern Australia. Quaternary Research 31, 392-395.

Prescott, J.R., Hutton, J.T., 1994. Cosmic ray contributions to dose rates for luminescence and ESR dating: large depths and longterm time variations. Radiation Measurements 23, 497-500.

Rees-Jones, J., 1995. Optical dating of young sediments using finegrain quartz. Ancient TL 13, 9-14.

Rees-Jones, J., Tite, M.S., 1997. Optical dating results for British archaeological sediments. Archaeometry 39, 177-187.

Reeves, J.M., Barrows, T.T., Cohen, T.J., Kiem, A.S., Bostock, H.C., Fitzsimmons, K.E., Jansen, J.D., Kemp, J., Krause, C., Petherick, L., 2013. Climate variability over the last 35,000 years recorded in marine and terrestrial archives in the Australian region: an OZ-INTIMATE compilation. Quaternary Science Reviews 74, 21-34.

Rudeva, I., Simmonds, I., Crock, D., Boschat, G., 2019. Midlatitude Fronts and Variability in the Southern Hemisphere Tropical Width. Journal of Climate 32, 8243-8260.

Sankey, J.B., Eitel, J.U.H., Glenn, N.F., Germino, M.J., Vierling, L.A., 2011. Quantifying relationships of burning, roughness, and potential dust emission with laser altimetry of soil surfaces at submeter scales. Geomorphology 135, 181-190.

Schnurrenberger, D., Russell, J., Kelts, K., 2003. Classification of lacustrine sediments based on sedimentary components. Journal of Paleolimnology 29, 141-154.

Shore, J.S., Bartley, D.D., Harkness, D.D., 1995. Problems encountered with the ${ }^{14} \mathrm{C}$ dating of peat. Quaternary Science Reviews 14 , 373-383.

Song, B., Kong, L., Hu, Z., Wang, Q., Yang, X., 2020. Pollen and diatom record of climate and environmental change over the last 170 years in Tingming Lake, Yunnan Province, SW China. Quaternary International 536, 85-91.

Svitok, M., Hrivnák, R., Ot’ahel'ová, H., Dúbravková, D., Pal'oveBalang, P., Slobodník, V., 2011. The importance of local and regional factors on the vegetation of created wetlands in Central Europe. Wetlands 31, 663-674.

Tejan-Kella, M.S., Chittleborough, D.J., Fitzpatrick, R.W., Thompson, C.H., Prescott, J.R., Hutton, J.T., 1990. Thermoluminescence dating of coastal sand dunes at Cooloola and North Stradbroke Island, Australia. Australian Journal of Soil Research 28, 456-481. 
Thompson, C.H., 1981. Podzol chronosequences on coastal dunes of eastern Australia. Nature 291, 59.

Tibby, J., Barr, C., Marshall, J., McGregor, G., Moss, P.T., Arnold, L.J., Page, T.J., et al., 2017. The persistence of wetlands on North Stradbroke Island (south-east Queensland, Australia) during the last glacial cycle: implications for Quaternary science and biogeography. Journal of Quaternary Science 32, 770-781.

Tjallingii, R., Röhl, U., Kölling, M., Bickert, T., 2007. Influence of the water content on X-ray fluorescence core-scanning measurements in soft marine sediments. Geochemistry, Geophysics, Geosystems 8, Q02004. https://doi.org/10.1029/2006GC001393.

Turney, C., Haberle, S., Fink, D., Kershaw, A.P., Barbetti, M., Barrows, T., Black, M., Cohen, T.J., Correge, T., Hesse, P., 2006a. Integration of ice-core, marine and terrestrial records for the Australian Last Glacial Maximum and Termination: a contribution from the OZ INTIMATE group. Journal of Quaternary Science 21, 751-761.

Turney, C.S.M., Kershaw, A.P., James, S., Branch, N., Cowley, J., Fifield, L.K., Jacobsen, G., Moss, P., 2006b. Geochemical changes recorded in Lynch's Crater, Northeastern Australia, over the past $50 \mathrm{ka}$. Palaeogeography, Palaeoclimatology, Palaeoecology 233, 187-203.

Vandergoes, M.J., Newnham, R.M., Preusser, F., Hendy, C.H., Lowell, T.V., Fitzsimons, S.J., Hogg, A.G., Kasper, H.U., Schlüchter, C., 2005. Regional insolation forcing of late Quaternary climate change in the Southern Hemisphere. Nature 436, 242-245.

Vogel, H., Zanchetta, G., Sulpizio, R., Wagner, B., Nowaczyk, N., 2010. A tephrostratigraphic record for the last glacial-interglacial cycle from Lake Ohrid, Albania and Macedonia. Journal of Quaternary Science 25, 320-338.

Walker, J., Lees, B., Olley, J., Thompson, C., 2018. Dating the Cooloola coastal dunes of south-eastern Queensland, Australia. Marine Geology 398, 73-85.
Ward, W.T., 2006. Coastal dunes and strandplains in southeast Queensland: sequence and chronology. Australian Journal of Earth Sciences 53, 363-373.

Washington, R., Todd, M.C., Lizcano, G., Tegen, I., Flamant, C., Koren, I., Ginoux, P., et al., 2006. Links between topography, wind, deflation, lakes and dust: The case of the Bodélé Depression, Chad. Geophysical Research Letters 33, L09401. https:// doi.org/10.1029/2006GL025827.

Webb, N.P., Strong, C.L., 2011. Soil erodibility dynamics and its representation for wind erosion and dust emission models. Aeolian Research 3, 165-179.

Weltje, G.J., Tjallingii, R., 2008. Calibration of XRF core scanners for quantitative geochemical logging of sediment cores: theory and application. Earth and Planetary Science Letters 274, 423-438.

Williams, M., Cook, E., van der Kaars, S., Barrows, T., Shulmeister, J., Kershaw, P., 2009. Glacial and deglacial climatic patterns in Australia and surrounding regions from 35000 to 10000 years ago reconstructed from terrestrial and near-shore proxy data. Quaternary Science Reviews 28, 2398-2419.

Woodward, C., Shulmeister, J., Bell, D., Haworth, R., Jacobsen, G., Zawadzki, A., 2014. A Holocene record of climate and hydrological changes from Little Llangothlin Lagoon, south eastern Australia. The Holocene 24, 1665-1674.

Xiao, X., Yao, A., Hillman, A., Shen, J., Haberle, S.G., 2020. Vegetation, climate and human impact since $20 \mathrm{ka}$ in central Yunnan Province based on high-resolution pollen and charcoal records from Dianchi, southwestern China. Quaternary Science Reviews 236, 106297. https://doi.org/10.1016/j.quascirev.2020.106297.

Zhang, J., Chen, F., Holmes, J.A., Li, H., Guo, X., Wang, J., Li, S., Lü, Y., Zhao, Y., Qiang, M., 2011. Holocene monsoon climate documented by oxygen and carbon isotopes from lake sediments and peat bogs in China: a review and synthesis. Quaternary Science Reviews 30, 1973-1987. 